\title{
MHC Class I Downregulation in Cancer: Underlying Mechanisms and Potential Targets for Cancer Immunotherapy
}

\author{
Annelisa M. Cornel ${ }^{1,+} \mathbb{D}$, Iris L. Mimpen ${ }^{1,+}$ and Stefan Nierkens ${ }^{1,2, * \mathbb{D}}$ \\ 1 Center for Translational Immunology, University Medical Center Utrecht, Utrecht University, \\ 3584 CX Utrecht, The Netherlands; a.m.cornel@umcutrecht.nl (A.M.C.); mimpeniris@gmail.com (I.L.M.) \\ 2 Princess Máxima Center for Pediatric Oncology, Utrecht University, 3584 CS Utrecht, The Netherlands \\ * Correspondence: snierken@umcutrecht.nl \\ $\dagger$ These authors have contributed equally to this work.
}

Received: 11 June 2020; Accepted: 29 June 2020; Published: 2 July 2020

\begin{abstract}
In recent years, major advances have been made in cancer immunotherapy. This has led to significant improvement in prognosis of cancer patients, especially in the hematological setting. Nonetheless, translation of these successes to solid tumors was found difficult. One major mechanism through which solid tumors can avoid anti-tumor immunity is the downregulation of major histocompatibility complex class I (MHC-I), which causes reduced recognition by- and cytotoxicity of CD8 ${ }^{+}$T-cells. Downregulation of MHC-I has been described in 40-90\% of human tumors, often correlating with worse prognosis. Epigenetic and (post-)transcriptional dysregulations relevant in the stabilization of NFkB, IRFs, and NLRC5 are often responsible for MHC-I downregulation in cancer. The intrinsic reversible nature of these dysregulations provides an opportunity to restore MHC-I expression and facilitate adaptive anti-tumor immunity. In this review, we provide an overview of the mechanisms underlying reversible MHC-I downregulation and describe potential strategies to counteract this reduction in MHC-I antigen presentation in cancer.
\end{abstract}

Keywords: MHC-I downregulation; cancer immunotherapy; antigen presentation; tumor immunogenicity; adaptive immune involvement

\section{Introduction}

In recent years, major advances have been made in cancer immunotherapy, thereby drastically improving the prognosis of cancer patients. Several types of Food and Drug Administration (FDA)-approved immunotherapies, such as checkpoint inhibitors (CPI), chimeric antigen receptor (CAR) T-cells, and dendritic cell vaccines, aim to boost T-cell-mediated cytotoxicity to combat cancer. These treatments led to increased survival chances, particularly for patients suffering from hematological cancers, but translation to the solid tumor setting was found difficult. Additional immune escape mechanisms, including immune checkpoint expression, induction of immunosuppressive immune subsets (e.g., regulatory T-cells and myeloid-derived suppressor cells (MDSCs)), loss of immunogenic antigens, and decreased antigen presentation allow these tumors to evade anti-tumor immunity (reviewed by Sharma et al. [1]), posing serious challenges to overcome in order to improve therapy response.

One way in which tumors can avoid tumor-associated antigen presentation, and therewith T-cell-mediated cytotoxicity, is the downregulation of surface display of major histocompatibility complex (MHC) class I, a crucial factor in the initiation of an adaptive immune response. The importance of MHC-I downregulation in immune evasion is substantiated by the observed correlations between 
MHC-I expression on tumor cells and the amount of tumor infiltrating lymphocytes (TILs) in several cancers [2,3]. Furthermore, several groups have reported impaired MHC-I antigen processing and presentation as a predictor of (acquired) resistance to CPI therapy [4-8] and adoptive cell therapy [9-11].

Downregulation of MHC-I has been described in 40-90\% of human tumors [9,12-20], often correlating with worse prognosis [18,21-29]. Both adult and pediatric tumors are able to reduce MHC-I surface display by the use of different regulatory mechanisms. Where adult tumors downregulate MHC-I expression in order to escape from the immune system, pediatric cancers, such as neuroblastoma, often arise from embryonic tissues that intrinsically lack immunological features, potentially explaining the low expression of MHC-I in these cancer types [30].

The intrinsic reversible nature of most MHC-I dysregulations provides an opportunity to restore MHC-I antigen presentation and facilitate adaptive anti-tumor immunity. This review aims to provide an overview of the mechanisms underlying reversible MHC-I downregulation and demonstrate potential therapeutic targets to induce MHC-I expression and improve T-cell-mediated cytotoxicity in cancer.

\section{Dysregulation of MHC-I Expression in Cancer}

T-cell receptors (TCRs) of CD8 ${ }^{+}$T-cells can only bind to their targets in the context of MHC-I, which is expressed on all nucleated cells. MHC-I presents endogenous antigens, a process important for reporting intracellular changes, for example caused by viral infections or malignant transformation, to the immune system in order to initiate a $\mathrm{CD}^{+} \mathrm{T}$-cell response. The heterodimer MHC-I consists of a heavy chain, encoded by the human leukocyte antigen (HLA)-A, HLA-B, and HLA-C genes, and an invariant light chain called $\beta_{2}$-microglobulin $\left(\beta_{2} \mathrm{M}\right)$. The heterodimer requires stabilization by a peptide, which is loaded into the MHC-I peptide-binding groove by the antigen processing machinery (APM).

Antigen presentation in MHC-I context is a complex, multi-step process which can be dysregulated at many levels. MHC-I and $\beta_{2} \mathrm{M}$ are synthesized in the endoplasmic reticulum (ER) and require stabilization by chaperone proteins (e.g., calreticulin, ERp57, and tapasin). Designated intracellular proteins are targeted for degradation by ubiquitination, after which they undergo proteasomal degradation into peptides. These peptides are subsequently translocated into the ER by the transporter associated with antigen processing (TAP) and bind to MHC-I directly or after further processing by ER aminopeptidases (ERAP1 and ERAP2). Interaction between tapasin and TAP allows translocation of peptides into the MHC-I binding groove, release of chaperone proteins, and stabilization of the MHC-I complex. Finally, the MHC-I-antigen complex travels via the Golgi apparatus to the cell surface, where antigen presentation to $\mathrm{CD} 8^{+} \mathrm{T}$-cells can start. In cancer, one or several proteins in this complex pathway can be dysregulated, which may have major consequences on cell surface display of MHC-I (Figure 1).

Although downregulation of surface expression of MHC-I allows evasion from T-cell-mediated anti-tumor immunity, low MHC-I expression sensitizes cells to Natural Killer (NK) cell-mediated cytotoxicity. MHC-I functions as an inhibitory ligand for NK-cells by binding to inhibitory receptors, such as killer cell immunoglobulin-like receptors (KIRs), thereby dampening NK-cell activation. Accordingly, when MHC-I is downregulated, the inhibitory signals initiated by MHC-I are no longer present, leading to enhanced NK-cell activation and cytotoxicity [31]. Nonetheless, tumors have developed several mechanisms to escape NK-cell-mediated cytotoxicity. For example, tumors often produce factors, such as transforming growth factor $\beta$ (TGF- $\beta$ ) and prostaglandin, that impair NK-cell function and block their infiltration into the tumor site [32]. Additionally, tumors may temporarily upregulate MHC-I expression in response to NK-cells, which allows them to avoid recognition by these cells $[19,22,33]$. As a result, tumors show plasticity in evading both NK- and T-cell-mediated cytotoxicity, thereby facilitating tumor immune escape. The importance of this plasticity is substantiated by the observation that colorectal cancer patients with reversible MHC-I downregulations have a worse prognosis compared to patients with irreversible MHC-I downregulations [22]. 


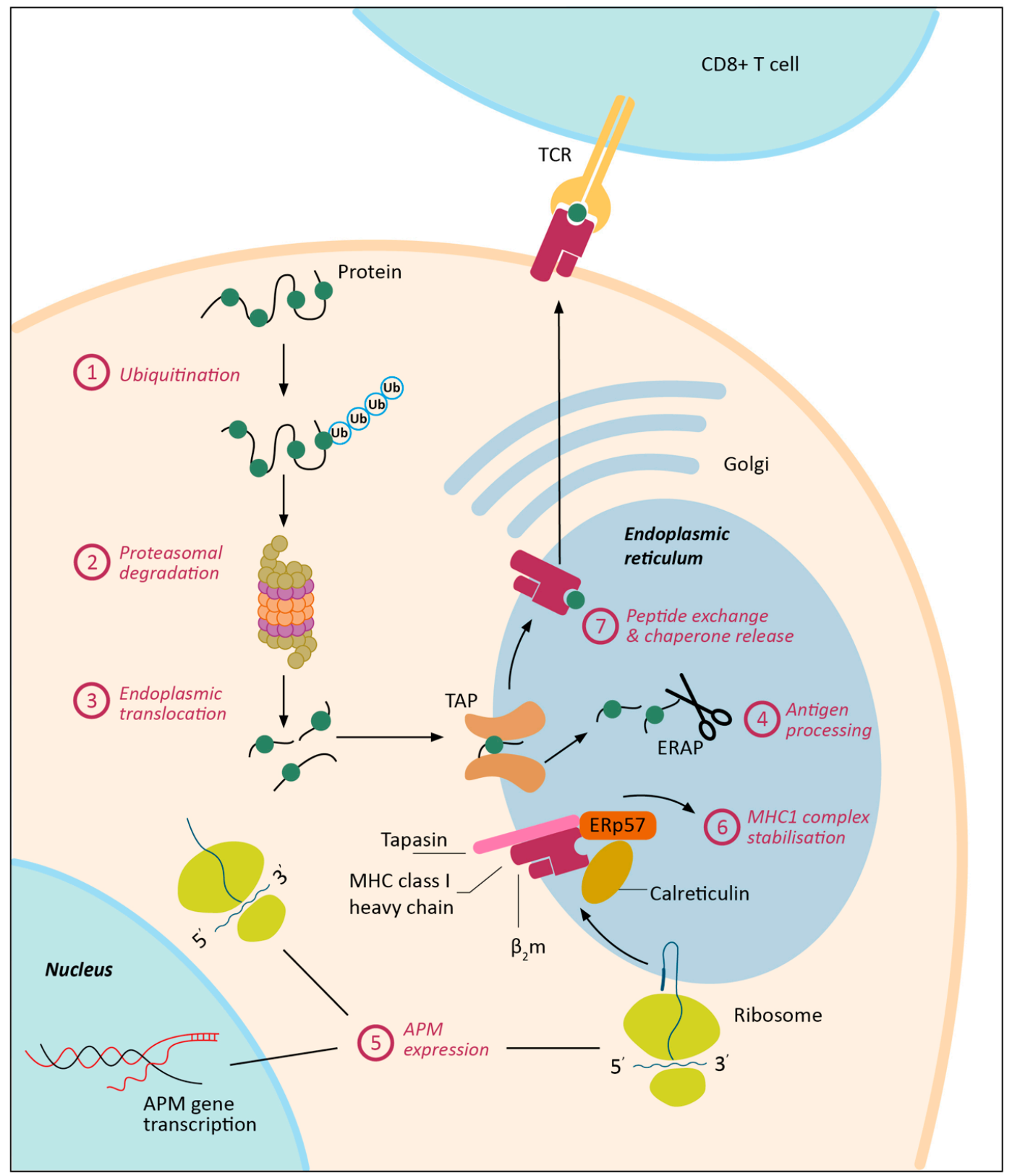

Figure 1. Major histocompatibility complex class I (MHC-I) antigen processing and presentation is a complex, multi-step process and can be dysregulated in cancer at multiple levels. APM = antigen processing machinery; ERAP = ER aminopeptidases; MHC-I = major histocompatibility complex I; $\mathrm{TCR}=\mathrm{T}$-cell receptor

Dysregulated cell surface display of MHC-I complexes may be caused by genetic, epigenetic, transcriptional, and post-transcriptional alterations, which leads either to irreversible or reversible changes in MHC-I expression. Irreversible MHC-I defects are described in multiple types of cancer, including melanoma, head and neck squamous cell carcinoma (HNSCC), and lung, colorectal, bladder, laryngeal, and breast cancer $[9,12-17]$ and arise due to structural genetic alterations, for example, in the class I heavy chain genes [12-14], $\beta_{2} \mathrm{M}[9,15,16]$, and the TAP-encoding genes [17]. As MHC-I expression cannot be upregulated in tumors harboring this type of mutations, these irreversible defects will not be the main focus of this review. Reversible MHC-I dysregulations are characterized by the coordinated (post-)transcriptional downregulation of the HLA class I heavy chain, components of the APM, or $\beta_{2} \mathrm{M}$ and have been observed in several types of tumors, including HNSCC, bladder 
cancer, and neuroblastoma [18-20]. The reversible nature of these pathway dysregulations makes them interesting targets in cancer immunotherapy.

\section{MHC-I Expression Regulation}

Three major transcription binding sites responsible for MHC-I heavy chain expression can be distinguished: an Enhancer A region, which can be recognized by NFkB; an interferon-stimulated response element (ISRE), which can be bound by interferon regulatory factor (IRF) 1; an SXY-module, which is recognized by NOD-like receptor family CARD domain containing 5 (NLRC5) [34]. Other APM genes are induced by the same set of transcription factors, resulting in the observation that the downregulation of APM players often coincides [35]. Accordingly, different pathways can lead to transcriptional activation of the MHC-I heavy chain-encoding genes as well as other genes responsible for the APM. In addition, these pathways can also act synergistically, magnifying the effect on MHC-I expression. By studying how MHC-I expression is normally regulated, we may be able to better understand the underlying mechanisms of MHC-I downregulation in tumors and find potential targets for cancer immunotherapy in order to reverse this downregulation.

\section{Inducing MHC-I Expression in Cancer via NFkB Stabilization}

The NFkB family consists of many inducible transcription factors, including NFkB1 (p50), NFkB2 (p52), RelA, RelB, and c-REL. During homeostasis, these proteins are sequestered in inactive cytosolic complexes by interaction with inhibitor of $\mathrm{kB}$ (IkB) family members (e.g., IkB $\alpha$ and p105). Upon pathway activation, IkB proteins are degraded, causing the release of NFkB transcription factors, allowing them to migrate to the nucleus to affect expression of target genes. Two major NFkB-inducing pathways can be distinguished: the canonical and the non-canonical NFkB pathway (Figure 2A,B) [36]. An elaborate description of pathway players important in this review can be found in Box 1. Although NFkB is constitutively active in most cancers [37], some tumors are able to downregulate NFkB signaling, which has been shown to impair MHC-I expression [35]. NFkB expression was found to be associated with favorable response to CPI therapy in patients with melanoma, indicating the potential of upregulating its expression to increase anti-tumor immunity [4,38]. To date, several regulators of the NFkB pathways have been described, revealing potential targets to enforce upregulation of MHC-I expression in cancer.

Box 1. NFkB-mediated upregulation of MHC-I.

The canonical NFkB pathway can be activated by stimulation of several immune receptors, including the TNF $\alpha$ Receptor (TNFR), Toll-like receptors (TLR), and cytokines receptors, by their ligands (e.g., TNF $\alpha$, IL-1, or LPS). Upon receptor stimulation, TRAF2/6 and receptor-interacting protein 1 (RIP-1) are recruited, after which TRAF2/6 polyubiquitinates itself and RIP-1. In addition, TGF- $\beta$-activated kinase 1 (TAK1) is ubiquitinated and activated. TAK1 in turn is able to phosphorylate and activate the IkB kinase (IKK) complex (consisting of IKK $\alpha$, IKK $\beta$, and NF-kappa-B essential modulator (NEMO) (also known as IKK $\gamma$ )). IKK needs to be recruited to the stimulated receptor before it can become phosphorylated, which is triggered by NEMO-mediated interaction of IKK with polyubiquitinated RIP-1 [39]. Subsequently, IKK phosphorylates IkB proteins, thereby targeting it for ubiquitination and degradation. Consequently, RelA-p50 and c-REL-p50 are released from their inactivating complexes, which results in translocation to the nucleus. Here they can activate transcription of their target genes, including MHC-I heavy chain- and other APM-encoding genes, by binding to kB enhancers in their promotors. A schematic overview of the canonical NFkB pathway can be found in Figure 2A [36].

Activation of the non-canonical NFkB pathway is initiated by the binding of a ligand (e.g., TNF $\alpha, C D 40 \mathrm{~L}$, or B-cell activating factor (BAFF)) to one of the TNFR superfamily members. NFkB-inducing kinase (NIK) becomes activated, which in turn is able to phosphorylate and activate IKK $\alpha$, one of the subunits of the IKK complex. IKK $\alpha$ subsequently phosphorylates the carboxy-terminal serine residues of $p 100$, which is an IkB-like molecule that sequesters the NFkB transcription factor RelB in the cytosol, resulting in ubiquitination and degradation of the C-terminus of p100. As a result, p52 is generated, which forms a heterodimer with RelB, thereby allowing migration to the nucleus, resulting in induction of transcription of target genes. A schematic overview of the non-canonical NFkB pathway can be found in Figure 2B [36]. 
A Canonical pathway

TNFR, TLR, cytokine receptor, antigen receptor

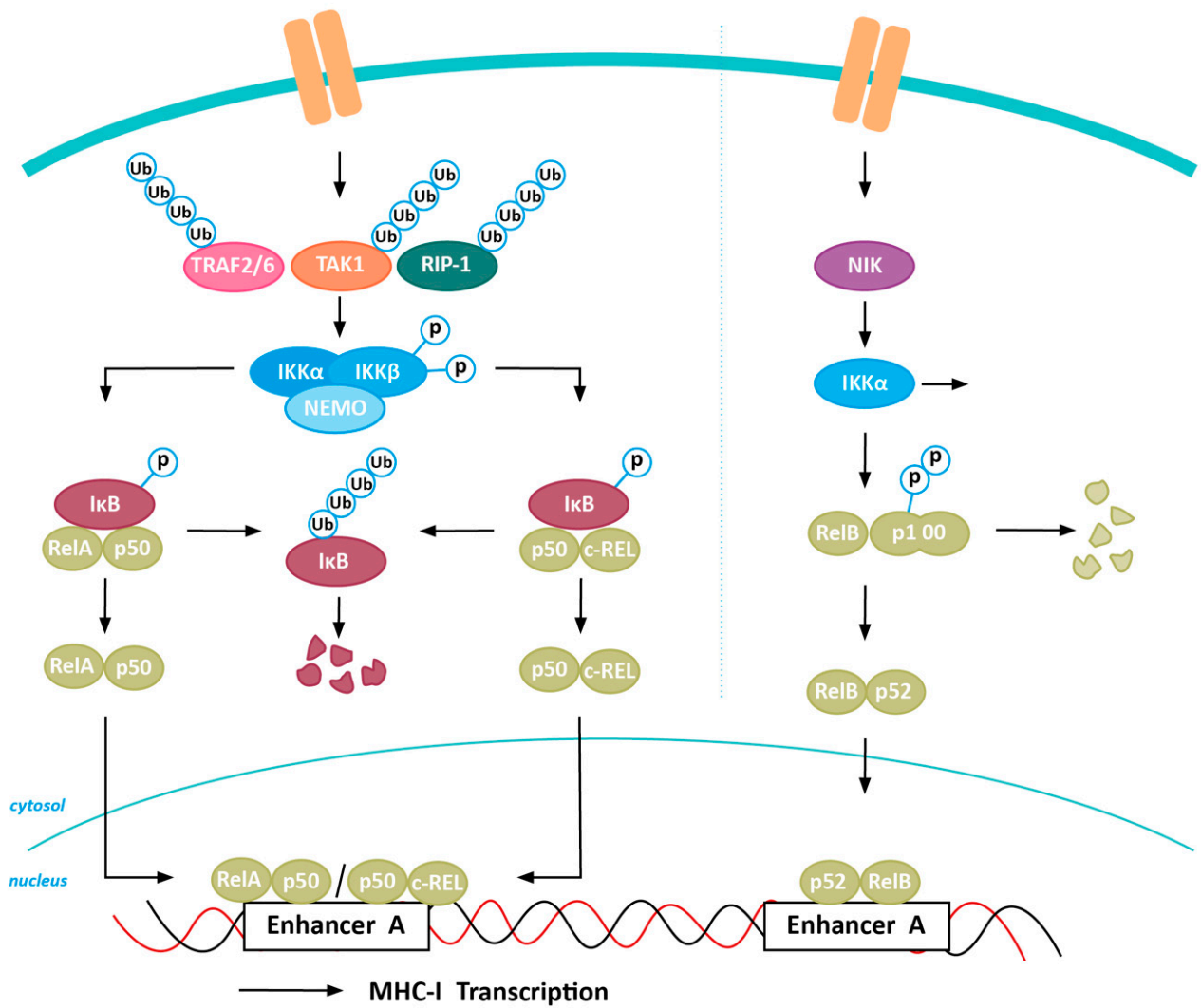

Figure 2. NFkB-induced expression of MHC-I. Transcriptional activation of MHC-I heavy chain, but also other genes encoding for antigen processing machinery (APM) proteins, can be initiated by both the canonical (A) and non-canonical (B) NFkB pathway. IkB = inhibitors of kB; IKK = IkB kinase; NEMO = NF-kappa-B essential modulator; NIK = NFkB-inducing kinase; RIP-1 = receptor-interacting protein 1; TAK1 $=$ TGF- $\beta$-activated kinase $1 ; \mathrm{TLR}=$ toll-like receptor; $\mathrm{TNFR}=\mathrm{TNF} \alpha$ receptor; TRAF $=$ TNF receptor-associated factor.

\subsection{Positive Regulators of NFkB Expression}

$\mathrm{TNF} \alpha$ forcefully stimulates NFkB signaling and subsequent MHC-I expression. However, its use in cancer therapy is limited due to severe toxicities [40]. Alternatively, retinoids have been described to induce MHC-I upregulation in cancer, which is suggested to be the result of stimulation of NFkB signaling, even though the exact mechanism is still under debate. Studies in neuroblastoma and embryonic carcinoma cells revealed that retinoids increase MHC-I expression via increased expression of NFkB p50 and RelA [41,42]. In addition, Vertuani et al. [43] reported that upregulation of proteasome subunits (Latent Membrane Protein (LMP)-2, -7, and -10) and increased half-life of MHC-I complexes are responsible for increased MHC-I expression in neuroblastoma cell lines. Retinoids are currently being used to treat several types of cancer, including neuroblastoma and promyelocytic leukemia, and are known to induce differentiation, apoptosis, and inhibition of proliferation of tumor cells [44].

Other compounds reported to positively affect NFkB signaling of which to date the effect on MHC-I expression has not been assessed, are betulinic acid, and calcium/calcineurin combined with protein kinase $\mathrm{C}$ (PKC) antagonists. Betulinic acid upregulates canonical pathway activity via boosting the activity of IKK as well as phosphorylation and degradation of $\mathrm{IkB} \alpha$ in multiple cancer cell lines, including neuroblastoma, glioblastoma, and melanoma [45]. In addition, it induces apoptosis, inhibits topoisomerase I activity, and suppresses angiogenesis in cancer [46-50]. Secondly, a study into latent HIV infections in CD4+ T-cells revealed that combining calcium/calcineurin and the protein kinase 
$\mathrm{C}$ (PKC) antagonist prostatin causes synergistic activation of NFkB through a similar mechanism as betulinic acid [51]. A third strategy would be to increase expression of the E3 ubiquitin ligase Nedd4 [52], which triggers polyubiquitination and proteasomal degradation of N4BP1 [53], a suppressor of NFkB. In addition, in B-cells, Nedd4 has been reported to induce ubiquitination and degradation of TNF receptor-associated factor (TRAF) 3 via the TNFR CD40, thereby inducing activation of both the canonical and non-canonical NFkB pathway [52]. However, to date, no Nedd4 stimulatory compounds have been described.

Nonetheless, dysregulation of factors affecting downstream signaling of NFkB-inducing pathways makes it questionable whether NFkB activity, and thus MHC-I expression, can be restored by upstream pathway activation. As a result, therapeutic intervention to inhibit negative regulators of NFkB may be a more effective strategy to explore.

\subsection{Negative Regulators of NFkB Expression}

The pediatric tumor neuroblastoma is well known for its low MHC-I expression. We have previously identified two major negative regulators of MHC-I via NFkB signaling in neuroblastoma: Nedd4 Binding Protein 1 (N4BP1) and TNF $\alpha$-induced protein 3 interacting protein 1 (TNIP1) [54]. TNIP1 affects canonical NFkB activation, whereas N4BP1 exerts an effect on both canonical and non-canonical pathway activation.

N4BP1 interacts with several proteins involved in (de)ubiquitination, including NEDD4, Cezanne-1, A20, and Itch $[53,54]$ and potentially also binds to polyubiquitin itself $[55,56]$. Polyubiquitin binding proteins, like N4BP1, can compete with NEMO for polyubiquitin binding, thereby directly antagonizing activation of canonical NFkB [56]. Besides this, N4BP1 interacts with the deubiquitinase (DUB) Cezanne-1, which functions in the deubiquitination and stabilization of TRAF3 [54] and subsequently modulates the activation of both the canonical [54] and non-canonical NFkB [57] by affecting the degradation of NIK and IkB, and the induction of c-REL ubiquitination and proteasome-mediated degradation [58].

TNIP1 (also known as A20-binding inhibitor of NF-kB (ABIN)-1) is known for its stimulatory effect on the NFkB inhibiting DUB A20 and inhibition of TNF-induced apoptosis and is upregulated in several types of cancer [59]. Similar to N4BP1, TNIP1 inhibits NFkB by impairing NEMO-mediated translocation of IKK to the receptor site. The exact mechanism remains unclear, but it is suggested to be via competing with NEMO binding to RIP-1 as well as via binding to a polyubiquitin group on NEMO itself [60]. TNIP1 is also able to prevent processing the IkB p105 into p50 [61] and to interact with the NFkB inhibiting DUB A20, stimulating deubiquitination of NEMO, thereby impairing IKK activation and thus canonical NFkB activation [62]. IL-17 treatment has been shown to induce proteasome-dependent downregulation of TNIP1 [63]. This resulted in NFkB activation, thereby suggesting its potential to upregulate MHC-I expression. However, IL-17 has been shown to play a key role in the promotion of tumor progression by inducing chronic inflammation, tumor cell proliferation, angiogenesis, and metastasis, which may majorly limit the use of this cytokine to induce MHC-I expression in cancer [64].

Hence, targeting N4BP1 or TNIP1 will result in strong activation of NFkB signaling, which in turn boosts MHC-I expression. Indeed microRNA (miR) 28-5p is an inhibitor of N4BP1 and has been demonstrated to act as a tumor suppressor in many cancer types, including colorectal cancer, renal cell carcinoma, and hepatocellular carcinoma [65-67]. In addition, MiR-1180 and miR-486 have also been demonstrated to induce NFkB activation via targeting of several inhibiting players of the NFkB pathway, including Cezanne, A20, and TNIP1-3 [68,69]. Nevertheless, it should be taken into account that these miRs have also been associated with cancer cell growth, survival, migration, and progression, emphasizing the need to further investigate the effect of these miRs in cancer [70,71].

The NFkB inhibiting DUB A20 is also involved in TNIP-independent regulation of NFkB signaling [72]. A20 can form a ubiquitin-editing complex together with the ubiquitin binding protein TAX1 Binding Protein 1 (TAX1BP1) and the E3 ubiquitin-protein ligase Itch. This complex 
can deubiquitinate RIP-1 and TRAF6, thereby inhibiting TAK1 activation as well as NEMO-mediated recruitment and activation of IKK. In addition, A20 can induce K48-polyubiquitination of RIP-1, thereby targeting it for proteasomal degradation [73]. TAX1BP1 is responsible for Itch recruitment to A20, whereas Itch controls the interaction between A20 and its substrates RIP-1 and TRAF6, enabling inactivation of these substrates. Knockout of either of these proteins results in inadequate NFkB inhibition, indicating that all three proteins are indispensable in the functioning of this ubiquitin-editing complex [74]. Itch has been shown to be upregulated in several types of cancer, such as breast cancer and neuroblastoma, in which it was shown to play a major role in cancer progression [75-79]. The antidepressant clomipramine, its structural homologue norclomipramine, and 1,4-naphthoquinone $10 \mathrm{E}$ have been shown to reduce tumor growth and enhance chemotherapy in multiple cancer cell lines, including breast, prostate, and bladder cancer lines, as well as in a multiple myeloma xenograft model [80,81]. In addition, clomipramine has been shown to induce MHC-I expression in a rat model of experimental allergic neuritis [82]. Controversially, N4BP1 has also been described to negatively regulate Itch by blocking the binding of Itch to its substrates [53]. However, as both N4BP1 and Itch play an important role in suppressing NFkB signaling, the potential for therapeutic inhibition of Itch remains elusive.

Another DUB enzyme, cylindromatosis (CYLD) plays a role in the inhibition of NFkB signaling through the removal of polyubiquitin motifs from NEMO and another important upstream protein in the NFkB signaling pathway called TRAF2 [83]. Several miRs have been reported to target CYLD, including miR-1288, -196, and -372-5p [84-86]. Recently, as reviewed by Farshi and colleagues, several DUB inhibitors have been developed for the treatment of cancer, all targeting different DUB enzymes that play distinct roles in the promotion of cancer [87]. To date, no specific DUB inhibitors have been described to specifically target Cezanne-1, A20, or CYLD. Nonetheless, aspecific DUB small molecule inhibitors, such as ubiquitin aldehyde (UbaI) have been described, which may suppress the activity of these NFkB targeting DUBs [87]. However, the use of aspecific inhibitors is limited due to the severe toxicity and simultaneous targeting of beneficial DUBs. Therefore, additional research should be conducted to develop specific DUB inhibitors. A patent (https://patentscope.wipo.int/search/en/detail. jsf?docId=WO2017109488, WO2017109488) describes cyanopyrrolidine derivates as specific inhibitors of Cezanne-1. In addition, as Cezanne-1 and A20 show sequence homology, it might potentially be possible to find cross-reactive DUB inhibitors to boost NFkB activity. However, in line with the above described miRs, Cezanne-1, A20, and CYLD are described in tumor suppressive as well as tumor progressive processes, which may be a counterindication for the use of inhibitors of these proteins in cancer [88,89].

Altogether, these studies show that there are multiple proteins that play a role in suppressing NFkB signaling, which may subsequently lead to hampered MHC-I expression. Several therapeutic interventions have been described, which could potentially trigger NFkB expression in cancer. A major contradiction we should be aware of is that the NFkB pathway is constitutionally active in a variety of tumors, playing an important role in many tumor-promoting processes, including inflammation, invasion, proliferation, angiogenesis, and metastasis [37]. This is further substantiated by the dual effect of most described proteins [53], miRs [68-71], and therapeutic interventions [53,64,75-78,88,89] affecting NFkB pathway induction on tumor-suppressing and tumor-promoting processes. It has been hypothesized that NF-kB inhibits tumor growth in cancers with a low mutational burden (early stages of cancer and potentially pediatric tumors), but that accumulation of mutations may lead to a loss of tumor suppressive function and the oncogenic features of NF-kB can become more dominant [90]. Therefore, we should carefully study the effects of NFkB pathway induction in NFkB-downregulated tumors as this could shift the balance from immune evasion towards tumor progression, thereby potentially even hampering the efficacy of cancer immunotherapy. 


\section{Inducing MHC-I Expression in Cancer via Restored IFN Signaling}

In addition to NFkB, Interferons (IFNs) play a significant role in the induction of MHC-I expression. During homeostasis, the signal transducer and activator of transcription (STAT) proteins are present in the cytosol in their inactive form. Upon pathway activation, STATs become phosphorylated and dimerize, allowing them to migrate to the nucleus to affect expression of target genes. Both type I and type II interferon pathways are able to induce dimerization of STATs, thereby upregulating MHC-I expression using different signaling pathways (Figure 3A,B). An elaborate description of pathway players important in this review can be found in Box 2. IFNs play an important role in the regulation of antigen processing and presentation and are described to exert pro- and anti-tumorigenic effects in various types of cancer as extensively reviewed by Musella et al. and Castro et al. [91,92]. Downregulation of both type I and II IFN-mediated pathways have been described as mechanisms involved in resistance to CPI- and adoptive cell therapy in melanoma and lung cancer, indicating the potential of interference in these pathways to increase anti-tumor immunity [4-6,10,93-96]. Several factors affecting IFN pathway expression have been described, revealing potential targets to modulate MHC-I expression in cancer.

A IFN type II

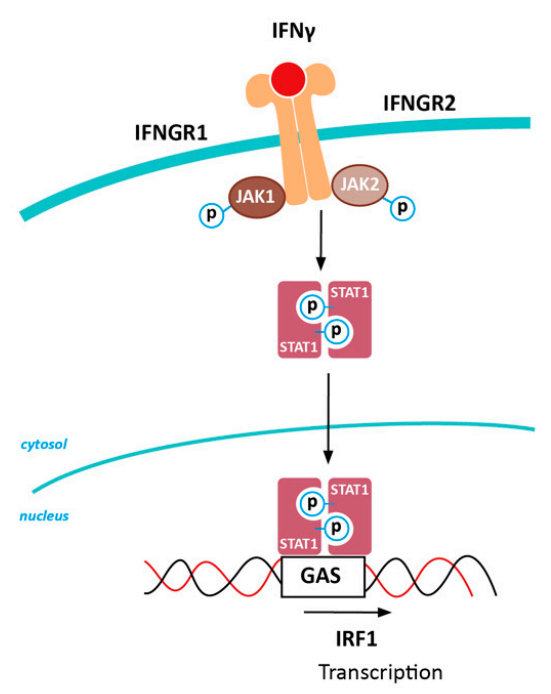

B IFN type I

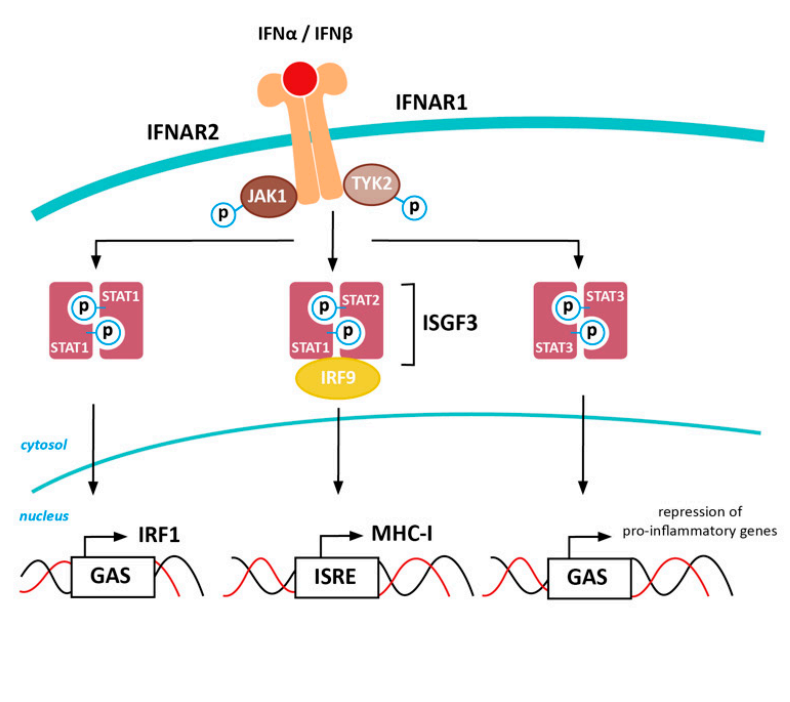

Figure 3. Interferon (IFN)-induced expression of MHC-I. Transcriptional activation of MHC-I heavy chain, but also other genes encoding for antigen processing machinery (APM) proteins, can be initiated by both the type II (A) and I (B) IFN pathway. GAS = gamma-activated site; IFNAR = IFN $\alpha$ receptor; IFNGR $=$ IFN $\gamma$ receptor; ISGF3 = IFN-stimulated gene factor 3; IRF = interferon regulatory factor; ISRE = interferon-stimulated response element; JAK = Janus Activated Kinase; STAT = signal transducer and activator of transcription; TYK2 = tyrosine kinase 2. 
Box 2. Interferon-mediated upregulation of MHC-I.

The type II IFN pathway can be activated by stimulation of the IFNG receptor (consisting of IFNGR1 and IFNGR2) by IFN $\gamma$, allowing binding, phosphorylation, and activation of Janus Activated Kinase (JAK) 1 and JAK2. The intracellular domain of IFNGR1 is phosphorylated, creating a docking site for signal transducer and activator of transcription (STAT)1, which is phosphorylated by JAK1/2, forms homodimers, and translocates to the nucleus to activate target gene expression via binding to gamma-activated site (GAS) elements in the promotor regions of IFN-stimulated genes (ISG). One of the genes induced by STAT1 signaling is the transcription factor IRF1, which in turn is able to bind to the ISRE site present in the MHC-I promoter [34]. A schematic overview of the type II IFN pathway can be found in Figure 3A [97].

Activation of the type I IFN pathway is initiated by binding of type I IFNs (e.g., IFN $\alpha$ and IFN $\beta$ ) to the IFNA receptor (consisting of IFNAR1 and IFNAR2), allowing binding, phosphorylation, and activation of JAK1 and tyrosine kinase 2 (TYK2). The cytoplasmic tail of IFNAR is phosphorylated, creating a docking site for STAT1-3, which are again phosphorylated by JAK1 to form homo and heterodimers. STAT1 homodimers can activate IRF1 expression as described for the type II IFN pathway. Additionally, STAT1/STAT2 forms a complex with IRF9 (called IFN-stimulated gene factor 3 (ISGF3), which is able to bind to the ISRE element in the MHC-I promotor. STAT3 homodimerization also occurs, however, this does not lead to MHC-I upregulation, but rather functions as a negative feedback loop to inhibit expression of pro-inflammatory genes. A schematic overview of the type I IFN pathway can be found in Figure 3B [98].

\subsection{Positive Regulators of IFN Signalling}

IFN signaling can be induced via treatment with IFN-inducing ligands, such as IFN $\alpha$, IFN $\beta$, and IFN $\gamma$. In addition, stimulation of several PRRs may result in downstream type I IFN production, thereby indirectly promoting MHC-I expression. IFN $\gamma$ has been suggested to have the most potent effect on the expression levels of APM genes, including MHC-I, TAP, and ERAP, which may imply its beneficial effect in cancer immunotherapy $[35,99,100]$. However, in line with NFkB-inducing ligands, IFNs and PRR stimulation initiates a broad range of biological activities, thereby limiting its use in cancer therapy due to severe toxicities [101]. To avoid toxicities, targeted delivery of IFN $\gamma$ to the tumor site may be of interest, for example by fusing it to an antibody specific for a tumor-associated antigen [102].

Another targeted approach would be a cellular NK-cell therapy strategy, as NK-cells are capable of either killing or upregulating MHC-I expression on MHC-I-lacking cells (via IFN $\gamma$ secretion) $[19,33,103]$. The potential of NK-cell therapy is substantiated by observed correlations between the abundance of functional NK-cells and checkpoint inhibition efficacy in non-small cell lung cancer (NSCLC) [104,105]. However, several challenges remain, including anti-inflammatory responses within the tumor microenvironment (TME), which cause impaired NK-cell function and TME infiltration [19,33,106,107], as well as ex vivo expansion to generate sufficient NK-cell numbers, and in vivo persistence [108]. The suggested ability of tumors to both evade NK- and T-cell mediated cytotoxicity via plasticity in MHC-I expression is one of the anti-inflammatory mechanisms potentially decreasing efficacy of NK-cell therapy. Interestingly, several studies have observed a beneficial outcome for individuals with an inhibitory KIR genotype with lacking HLA-ligands (the 'missing ligand' genotype) undergoing cancer immunotherapy, as inhibitory KIRs without matching HLA-ligands cannot inhibit NK-cell cytotoxicity $[109,110]$. This led to the rationale of allogeneic, KIR genotype-mismatched NK-cell therapy strategies to optimize NK-cell cytotoxicity by decreasing HLA-dependent inhibition of NK-cells [111]. Besides this, it should be considered that the immune checkpoint programmed cell death-ligand 1 (PD-L1) is also shown to be upregulated by IFN $\gamma[112,113]$. As a result, IFN $\gamma$ simultaneously induces MHC-I upregulation and T-cell suppression, thereby potentially creating a vicious circle of T-cell activation and inhibition.

\subsection{Negative Regulators of IFN Signaling}

The embryonic transcription factor double homeobox 4 (DUX4) has been shown to be upregulated in many cancer types, in which it causes downregulation of JAK1/2 and STAT1, thereby suppressing IFN target gene transcription, including MHC-I and other APM genes [114]. In line with this, DUX4 
has been demonstrated to be significantly upregulated in non-responders to CPI, indicating that the DUX4-induced reduction in MHC-I expression results in decreased T-cell cytotoxicity in patients [114]. The exact mechanism in which DUX4 downregulates JAK1/2 and STAT1 remains to be elucidated. As DUX4 is studied in more detail in a disease called facioscapulohumeral dystrophy (FSHD), knowledge on treatment strategies could be gained from this disease. Bosnakovski et al. [115] reported that inhibition of p300, a histone acetyltransferase recruited by DUX4 to affect target gene expression, by a specific inhibitor, counteracted the effect DUX-4 overexpression in vitro and in vivo. Others reported before that p300 inhibition in multiple types of cancer led to suppressed proliferation [116]. However, whether p300 inhibition also restores IFN signaling remains to be elucidated. DUX4 downregulation was also observed when treated with p38 inhibitors in vitro and in vivo in FSHD models [117]. P38 inhibition has a favorable effect in cancer treatment, however, the wide variety of processes in which p38 is involved, including tumor suppressive processes, is a clear disadvantage of this inhibitor [118].

Lymphocyte adapter protein (LNK) has been reported to be able to negatively regulate IFN signaling via the induction of dephosphorylation of STAT1 [119,120]. LNK has been shown to be overexpressed in several solid tumors, including melanoma and ovarian cancer, and was found to be significantly increased in patients who did not respond to CPI therapy [120]. LNK has been reported to be targeted by miR-29b, miR-30-5p, miR-98, miR-181a-5p [121,122]. To date, no other therapeutic LNK inhibitors have been reported.

The peptidyl-prolyl isomerase Pin1 has been reported to induce ubiquitination and degradation of the type I IFN inducing transcription factor IRF3, which normally triggers a positive feedback loop upon type I IFN pathway stimulation [123]. Pin1 has been demonstrated to be elevated in multiple types of cancer, playing a role in stimulating several cancer-driving processes [124]. As Pin1 is involved in downregulating type I IFN signaling, its suppression may lead to enhanced MHC-I expression, thereby advancing T-cell-mediated cytotoxicity. Presently, several Pin1 inhibitors have been developed, such as miR-200b, miR-200c, and miR296-5p, the small molecules all-trans retinoic acid (ATRA) and KPT-6566, and the natural compound Juglone, which all showed anti-cancer activity in different types of cancer [125-130].

Several protein tyrosine phosphatases (PTPs) have been described to downregulate tyrosine phosphorylation in the JAK/STAT pathway, thereby interfering with induction of both type I and II IFN signaling. For example, PTPN1 dephosphorylates TYK2 and JAK2 [131], PTPN2 dephosphorylates JAK1, and PTPN11 (SHP2) has been demonstrated to inhibit phosphorylation of JAK1, STAT1, and STAT2 [132]. Tyrosine phosphatases have been shown to be elevated in multiple types of cancer, including breast, ovarian, gastric cancer, and glioma, in which they promote tumor growth, survival, and metastases [133]. To date, several efforts have been attempted in the development of tyrosine phosphatase inhibitors, including the PTPN11 inhibitor sodium stibogluconate, and the PTP1B inhibitor MSI-1436C, which are now being tested in clinical trials for various cancer types [133-135]. In addition, miR-155 has been reported to target several negative regulators of IFN signaling, including PTPN2, which has been shown to result in increased IFN $\gamma$ production by T-cells within the TME, thereby promoting MHC-I expression [136]. In contrast, miRNA-155 has been demonstrated to be overexpressed in multiple types of cancer, playing a pivotal role in oncogenesis, which may limit its use in cancer [137].

The ubiquitin ligases RING finger protein 2 (RNF2) and Smad ubiquitination regulatory factor-1 (Smurf1) and the protein inhibitor of activated STAT (PIAS) all function via inhibiting transcription activation of STAT1 [138-140]. These proteins have been shown to be overexpressed in several types of cancer, including melanoma, gastrointestinal tumors, lymphoma, and pancreatic cancer, thereby playing an active role in cancer promotion [141-146]. Likewise, the ubiquitin ligase DCST1 is able to induce ubiquitination and degradation of STAT2, which results in hampered type I IFN signaling and has also been shown to be elevated in various cancers [147]. The small molecule inhibitors PRT4165 and A01 successfully inhibit, respectively, RNF2 and Smurf1 in vitro [148,149]. In addition, indirect 
inhibition of RNF2 was reported via inhibition of MEK-induced activation by the MEK-inhibitor trametinib [143]. To date, no DCST1 inhibitors have been described.

Finally, the protein kinase D2 (PKD2) has been shown to dampen type I IFN signaling via stimulating ubiquitination and endocytosis of IFNAR1, thereby causing rapid turnover of the type I IFN receptor [150]. PKD2 has been associated with multiple types of cancer, functioning by promoting tumor progression and blocking type I IFN signaling [151]. To date, several inhibitors of PKD2 have been developed, for example the small molecule inhibitor CRT0066101 and the pyrazolopyrimidine pan-PKD inhibitor SD-208, which both show anti-tumor activity in xenograft mouse models of various cancers $[152,153]$.

Taken together, several proteins have been implicated in impaired IFN signaling in cancer. Accordingly, therapeutic intervention of these dysregulations may be beneficial when combined with immunotherapy to increase MHC-I expression and enhance T-cell-mediated cytotoxicity. However, many of these proteins have not been associated with MHC-I downregulation before, highlighting the need to investigate their effect on MHC-I expression. In addition, as stated for NFkB, IFNs are also reported to exert both pro- and anti-tumorigenic effects in various types of cancer [91,92], indicating the need to closely study these effects.

\section{NLRC5-Mediated Upregulation of MHC-I}

Only recently, NLRC5 was discovered as a third key regulator of MHC-I transcription [154]. NLRC5 is expressed in response to IFN-mediated signaling, in particular via IFN $\gamma$, by binding of a STAT1 homodimer to GAS in the NLRC5 promoter $[154,155]$. Interestingly, this STAT1 binding site in the NLRC5 promoter was shown to partially overlap with an NFkB binding site, suggesting that NLRC5 expression may be induced by NFkB as well [156]. Moreover, it has been suggested that the NLRC5 promoter contains an ISRE site, which may allow transcriptional activation by IRF1. Upon its expression, NLRC5 migrates to the nucleus, where it assembles with several proteins, including RFX, ATF1/CREB, and the NFY complex, resulting in the formation of the MHC enhanceosome. This complex is able to bind the SXY module in the MHC-I promoter, causing the induction of MHC-I expression. Additionally, NLRC5 is able to recruit transcriptional initiation and elongation factors, and histon-modifying enzymes, for example histon acetyltransferases and methyltransferases, which may further enhance transcriptional activation of MHC-I [82,157]. (Epigenetic) downregulation of NLRC5 expression has been observed as a mechanism of immune evasion in several types of cancer, including colorectal, ovarian, breast and uterine cancers $[158,159]$. NLRC5 has been reported to elicit anti-tumor immunity by enhancing antigen processing and presentation in melanoma [160]. In addition, NLRC5 expression correlates with response to CPI in melanoma (https://pubchem.ncbi.nlm.nih.gov/patent/US2017321285, US20170321285A1). Controversially, as also observed for NFkB- and IFN-mediated signaling pathways, NLRC5 has been reported to exert both pro- and anti-tumorigenic effects in various types of cancer (reviewed by Tang et al. [161]), indicating the need of careful evaluation of upregulation of NLRC5 in cancer. To date, no specific NLRC5 targeting compounds have been described. Nonetheless, as NLRC5 activation pathways largely overlap with the above described pathways, compounds inducing these pathways may also result in NLRC5 activation.

\section{Inducing MHC-I Expression in Cancer via STAT3 Inhibition}

As briefly touched upon in the section above, STAT3 becomes activated upon type I IFN signaling to function as a negative feedback loop to inhibit expression of pro-inflammatory genes, thereby contributing to balanced immune responses [98]. STAT3 is implicated in dampening a variety of immune responses, including inhibition of both NFkB- and IFN-mediated pathways. STAT3 is able to inhibit activation of the IKK-complex, thereby preventing phosphorylation and degradation of IkB, which results in sequestering of NFkB transcription factors in the cytosol.

STAT3 has been shown to play a key role in the promotion of cancer by mediating proliferation, survival, invasion, and metastasis [162]. STAT3 inhibition resulted in increased anti-tumor activity 
and superior responses to immunotherapy and immunogenic chemotherapy in several pre-clinical studies and trials [163-172]. Combinations of CPI and STAT3 inhibitors are currently tested in clinical trials [173]. STAT3 can be inhibited via upstream JAK inhibition as well as by direct inhibition of STAT3. Several specific STAT3 inhibitors have been described, including JSI-124 (cucurbitacin I) [163], static [166], indirubin [164], resveratrol [165], and the antibiotic nifuroxazide [170]. In addition, the multitarget tyrosine kinase inhibitors sorafenib and sunitinib are also reported to specifically target STAT3 phosphorylation and activation $[167,168]$.

As STAT3 overexpression inhibits both NFkB- and IFN-signaling pathways, specific inhibition of STAT3 may be an interesting strategy to target downregulation of these pathways and potentially induce MHC-I upregulation. However, as is the case for other NFkB- and IFN-signaling pathway inhibitors, these pathway inhibitors also exhibit favorable effects, as for example indicated by the fact that STAT3 also elicits tumor-suppressive functions [174].

\section{Inducing MHC-I Expression in Cancer via STING Induction}

Stimulator of Interferon Genes (STING) is a DNA-sensing molecule which activates upon encountering foreign DNA by cyclic dinucleotide recognition [175]. Upon cyclic dinucleotide recognition, STING becomes activated and forms a complex with TANK-binding kinase 1 (TBK1), which in turn is able to phosphorylate and activate both RelA and IRF3, thereby stimulating both NFkB- and type I IFN-activation [176]. To date, several STING agonists have been developed to exploit this response in cancer. One example is the STING agonist SB 11285, which is currently tested in clinical trials in several solid tumors, including HNSCC and melanoma (ClinicalTrials.gov Identifier: NCT04096638), and previously showed strong anti-tumor immunity induction in mouse models [177].

As STING induced both NFkB- and IFN-pathway activation, agonizing its activity may be an interesting strategy to upregulate these pathways to potentially induce MHC-I upregulation. This is further substantiated by the correlation between STING expression and HLA-associated genes in neuroblastoma [178]. In addition, preclinical studies have reported superior effects of CPI therapy in combination with STING agonists [179,180]. Combining CPI with STING agonists is currently being tested in clinical trials [181]. The multi-facet involvement of STING in immune activation, however, underlines the need to study its effect to improve therapy outcomes while not compromising treatment safety.

\section{Well-Known Oncogenic Pathways Affect MHC-I Expression}

Various oncogenic pathways have been reported to affect expression of MHC-I, $\beta_{2} \mathrm{M}$, and other APM components in cancer, including the MAPK-, epidermal growth factor receptor (EGFR), HER2, c-MYC, and n-MYC pathway [182-187]. MAPK pathway activation is suggested to negatively influence MHC-I expression via decreased IRF1 activity and STAT1 expression [188]. The MEK inhibitors trametinib and cobimetinib have been demonstrated to enhance IRF1 expression and increased STAT1 phosphorylation in human keratinocytes [188]. Watanabe et al. [189] reported that treatment of a NSCLC cell line with trametinib also increased MHC-I expression in vitro. Another MEK inhibitor, selumetinib, increased MHC-I expression in papillary thyroid cancer cell lines [2]. In addition, upstream inhibition of BRAF by vemurafenib and dabrafenib also induced MHC-I and $\beta_{2} \mathrm{M}$ upregulation in multiple melanoma cell lines [190].

Overexpression of the EGFR family member HER2/neu was shown to be inversely correlated with MHC-I expression in different types of cancer, including breast cancer, esophageal squamous cell carcinoma, and melanoma [191,192]. Additionally, overexpression of EGFR was associated with less potent responses to cancer immunotherapy in NSCLC and neuroblastoma [193,194]. EGFR activates PTNP11, which was mentioned above as a STAT1 inactivator [195]. PTNP11 also inhibits RAS GTPase-activating protein, which normally functions in downregulating MAPK signaling, thereby also contributing to impaired IFN signaling via the MAPK pathway [196]. A third mechanism in which EGFR signaling impairs MHC-I expression is the promotion of STAT3 activation [197]. HER2 in 
turn also induces proteasomal degradation of the tumor suppressor Fhit, which normally upregulates expression of MHC-I, APM components, and $\beta_{2} \mathrm{M}$ via an as-yet unclear mechanism [142]. Hence, targeting tyrosine kinase receptors, for example by the anti-EGFR antibodies nimotuzumab and cetuximab, and the EGFR inhibitors afatinib, erlotinib, and gefitinib, results in enhanced expression of MHC-I and APM components in different cancer cell lines as well as in cancer patients [185,198-202].

Finally, oncogenes c- and n-MYC have both been associated with MHC-I downregulation [186,187,203]. N-MYC has been shown to decrease MHC-I expression in rat neuroblastoma cell lines through the inhibition of the NFkB transcription factor p50 [203]. On the contrary, Forloni et al. [204] showed that that the downregulation of MHC-I in human neuroblastoma cells was not caused by n-MYC. In line with this, we did not identify n-MYC as a negative regulator of NFkB [54]. However, one limitation of our study was the use of an early phase CRISPR/Cas 9 library, which impairs the ability to fully confirm the results found in previous studies. Recently, Yang and colleagues showed that c-MYC expression induction by the Wnt/B-catenin pathway is responsible for MHC-I downregulation in glioma [187]. This again hints towards involvement of MYC-family members in MHC-I expression regulation in cancer.

Altogether, by targeting these oncogenic pathways, we potentially will not only be able to impair tumor growth and proliferation, but also exhibit anti-tumor responses via increasing the immunogenicity of the tumor.

\section{Chemotherapy- and Radiation-Induced MHC-I Expression}

Certain chemotherapeutic therapy regimens are known to induce anti-tumor immune responses without inducing classical immunogenic cell death (ICD). Hodge and colleagues showed that both docetaxel-induced ICD-sensitive and resistant tumor cells expressed increased levels of APM components, including TAP2, calnexin and calreticulin [205]. In addition, immunochemotherapy combining IFN $\alpha$ and 5-fluorouracil treatment resulted in increased MHC-I expression via STAT1/2 activation in murine pancreatic cancer models [206]. Besides this, several topoisomerase inhibitors (e.g., topotecan, irinotecan, and etoposide), microtubule stabilizers (e.g., paclitaxel and vinblastine), cisplatin, and ionizing radiation elevate MHC-I surface expression, which is thought to be induced via NFkB stabilization and IFN $\beta$ secretion [207-209]. These studies indicate that cytostatic drugs may, besides direct induction of cell death, also be involved in decreasing tumor immune escape via upregulation of antigen presentation, thereby making these drugs interesting candidates for combination therapy to improve immunotherapeutic strategies in cancer.

\section{Epigenetic Silencing Affecting MHC-I Expression}

Another common reversible defect in MHC-I antigen presentation is the occurrence of epigenetic modulation, which may impair the transcription of MHC-I, APM components, $\beta_{2} \mathrm{M}$, or MHC-I regulatory proteins. Histon deacetylation (HDAC) has been reported to reduce expression of $\mathrm{MHC}-\mathrm{I}$ and key components of the APM, such as the proteasome subunits LMP-2 and LMP-7, and TAP in multiple types of cancer, including neuroblastoma, glioma, Merkel cell carcinoma, cervical cancer, and melanoma [187,210-212]. HDAC inhibitors, of which several already are FDA approved (e.g., Romidepsin, Vorinostat and Panobinostat), show increased expression of MHC-I and APM components both in vitro and in vivo [187,210,211,213]. Multiple other HDAC inhibitors are currently tested in clinical trials either alone or in combination with other drugs in various types of cancer, including melanoma, breast cancer, and lung cancer [214].

Epigenetic modulation by DNA hypermethylation has also been reported to cause reduced expression of MHC-I and related genes, which may be reversed by treatment with DNA methyltransferase inhibitors (DNMTi). The DNMTis guadecitabine, 5-azacytidine, and decitabine increased MHC-I expression in breast cancer, melanoma, and neuroblastoma cell lines [54,215-217]. Interestingly, combinatory treatment with $\mathrm{TNF} \alpha, \operatorname{IFN} \gamma$, or knockout of known inhibitors of NFkB signaling (TNIP and N4BP1) further exaggerated the effect of these epigenetic modulators $[54,215,217]$. 
Additionally, increased MHC-I expression was observed in breast cancer patients treated with a combination of DNMT and HDAC inhibitors [216], indicating the potential of epigenetic modification to reintroduce MHC-I expression in tumors.

\section{Discussion}

MHC-I-mediated antigen presentation is crucial for $\mathrm{CD} 8^{+} \mathrm{T}$-cell cytotoxicity and is one of the key factors in endogenous adaptive immune response development as well as T-cell mediated immunotherapy efficacy in cancer. The often intrinsically reversible nature of these dysregulations provides an opportunity to restore MHC-I expression and therewith adaptive anti-tumor immunity. In this review, we highlight that MHC-I-mediated antigen presentation is a complex, multi-faceted process, which can be dysregulated at many levels. As APM players are often induced by the same set of transcription factors, downregulation of APM players often coincides. To identify therapeutic targets to increase immunotherapy efficiency in cancer, a better understanding of the underlying mechanisms of MHC-I downregulation in tumors is required. A summary of regulators of MHC-I expression and potential therapeutic strategies described in this review can be found in Table 1 and Figure 4.

Dysregulation of factors affecting the downstream signaling of MHC-I-inducing pathways makes it questionable whether pathway activity can be restored by upstream pathway activation. As a result, therapeutic intervention to inhibit negative regulators of these pathways, possibly combined with stimulation of positive regulators of these pathways, may be the most promising strategy to explore.

Downregulation of MHC-I is an important factor contributing to the immune evasion of tumors. However, as underlined by the observed resistance of solid tumors to CAR-therapy as well as by IFN $\gamma$-mediated upregulation of PD-L1 [112,113], immune evasion of tumors is a multifaced process. As a result, the authors hypothesize that combination therapy targeting several tumor-immunomodulatory processes simultaneously will be necessary to avoid immune evasion of tumors. Several combinations of immunomodulatory drugs, including combining CPI with STAT3 inhibitors or STING agonists, show promising results in (pre-)clinical studies [171-173,179-181].

An important contradiction in enhancing NFkB-, IFN-, and NLRC5-mediated MHC-I expression is the dual role of these pathways in cancer $[37,91,92,161]$. They have been described in both tumor-promoting as well as tumor-suppressive mechanisms in several types of cancer. The authors hypothesize that, depending on the activation status of these pathways, its function will either be to promote or suppress tumor progression. Hence, it is important to study the effect of (pharmacological) enhancement of these pathways in MHC-I lacking tumors, as overactivation might shift the balance from immune evasion towards tumor progression. However, the observation that several NFkB/IFN upregulatory drugs do show beneficial effects in the treatment of several types of cancer highlights the potential of these drugs in improving immunotherapy outcomes in cancer. 
Table 1. Overview of described pathways and potential therapeutic strategies to boost MHC-I antigen presentation.

\begin{tabular}{|c|c|c|c|c|c|}
\hline Regulation & Pathway & Effector & Described Mechanism(s) & Potential Therapeutic Strategy & Clinical Status \\
\hline \multirow{11}{*}{$\begin{array}{l}\text { Negative } \\
\text { Regulators }\end{array}$} & \multirow{7}{*}{ NFkB pathway } & N4BP1 & $\begin{array}{l}\text { 1. Cezanne-1 stabilization } \\
\text { 2. Preventing recruitment of } \\
\text { NEMO to RIP1 }\end{array}$ & miRNA-28-5p [65-67,70,71] & Pre-clinical \\
\hline & & Cezanne-1 & $\begin{array}{l}\text { Deubiquitination and } \\
\text { stabilization of TRAF3 }\end{array}$ & $\begin{array}{c}\text { Aspecific DUB inhibitors (e.g., Ubal) [87] } \\
\text { miR-1180 [69], miR-486 [68] } \\
\text { Cyanopyrrolidine derivates } \\
\text { (WO2017109488) }\end{array}$ & Pre-clinical \\
\hline & & TNIP1 & $\begin{array}{l}\text { 1. Preventing recruitment of } \\
\text { NEMO to RIP1 } \\
\text { 2. Preventing degradation of the } \\
\text { IkB p105 into p50 } \\
\text { 3. A20 stabilization }\end{array}$ & $\begin{array}{c}\text { IL-17 [63] } \\
\text { miR-1180 [69], miR-486 [68] }\end{array}$ & Pre-clinical \\
\hline & & A20 & $\begin{array}{l}\text { 1. Deubiquitination of NEMO } \\
\text { 2. Deubiquitination of RIP-1 and } \\
\text { TRAF6 } \\
\text { 3. Degradation of RIP-1 }\end{array}$ & $\begin{array}{c}\text { Aspecific DUB inhibitors (e.g., Ubal) [87] } \\
\text { miR-1180 [69], miR-486 [68] }\end{array}$ & Pre-clinical \\
\hline & & TAX1BP1 & Itch recruitment to A20 & & \\
\hline & & Itch & $\begin{array}{l}\text { Controlling interaction between } \\
\text { A20 and RIP1/TRAF6 }\end{array}$ & $\begin{array}{l}\text { Clomipramine and norclomipramine [80] } \\
\text { 1,4-naphthoquinone 10E [81] }\end{array}$ & $\begin{array}{l}\text { FDA-approved antidepressants } \\
\text { Pre-clinical }\end{array}$ \\
\hline & & CYLD & $\begin{array}{l}\text { 1. Deubiquitination of NEMO } \\
\text { 2. Deubiquitination of TRAF2 }\end{array}$ & $\begin{array}{l}\text { miR-1288 [84], miR-186 [85], } \\
\text { miR-362-5p [86] }\end{array}$ & Pre-clinical \\
\hline & \multirow{4}{*}{$\begin{array}{l}\text { Type I/II IFN } \\
\text { pathway }\end{array}$} & DUX4 & $\begin{array}{l}\text { 1. JAK } 1 / 2 \text { downregulation } \\
\text { 2. STAT2 downregulation }\end{array}$ & $\begin{array}{l}\text { p300 inhibitors [115] } \\
\text { p38 inhibitors [117] }\end{array}$ & $\begin{array}{c}\text { Pre-clinical } \\
\text { Several Phase II Trials (Rheumatoid } \\
\text { Arthritis, Asthma, LMNA-related } \\
\text { cardiomyopathy) }\end{array}$ \\
\hline & & LNK (SH2B3) & Dephosphorylation of STAT1 & $\begin{array}{l}\text { miR-29b [122], miR-30-5p [121], } \\
\text { miR-98 [121], miR181a-5p [121] }\end{array}$ & \\
\hline & & PTPN1 (PTP1B) & $\begin{array}{l}\text { 1. Dephosphorylation of TYK2 } \\
\text { 2. Dephosphorylation of JAK2 }\end{array}$ & MSI-1436C [135] & Phase I Trial, metastatic breast cancer \\
\hline & & PTPN2 (TC-PTP) & 1. Dephosphorylation of JAK1 & miRNA-155 [136] & Pre-clinical \\
\hline
\end{tabular}


Table 1. Cont

\begin{tabular}{|c|c|c|c|c|c|}
\hline Regulation & Pathway & Effector & Described Mechanism(s) & Potential Therapeutic Strategy & Clinical Status \\
\hline & & PTPN11 (SHP2) & $\begin{array}{l}\text { 1. Dephosphorylation of JAK1 } \\
\text { 2. Dephosphorylation of STAT1 } \\
\text { 3. Dephosphorylation of STAT2 }\end{array}$ & Sodium stibogluconate [134] & $\begin{array}{l}\text { Phase II Trial, Leishmaniasis, stage IV } \\
\text { melanoma, advanced solid tumor }\end{array}$ \\
\hline & & RNF2 & $\begin{array}{l}\text { Polyubiquitination of STAT1, } \\
\text { resulting in release from DNA }\end{array}$ & $\begin{array}{l}\text { Trametinib [143] } \\
\text { PRT4165 [148] }\end{array}$ & $\begin{array}{c}\text { FDA-approved in several advanced-stage } \\
\text { cancers } \\
\text { Pre-clinical }\end{array}$ \\
\hline & & Smurf1 & Degradation of STAT1 & A01 [149] & Pre-clinical \\
\hline & & PIAS & $\begin{array}{l}\text { Inhibiting STAT1 promotor } \\
\text { recruitment }\end{array}$ & & \\
\hline & \multirow{3}{*}{$\begin{array}{l}\text { Type I IFN } \\
\text { pathway }\end{array}$} & DCST1 & $\begin{array}{l}\text { Ubiquitination and degradation } \\
\text { of STAT2 }\end{array}$ & & \\
\hline & & PKD2 & $\begin{array}{l}\text { Stimulating ubiquitination and } \\
\text { endocytosis of IFNAR1 }\end{array}$ & $\begin{array}{l}\text { CRT0066101 [152] } \\
\text { SD-208 [153] }\end{array}$ & Pre-clinical \\
\hline & & Pin1 & $\begin{array}{l}\text { Ubiquitination and degradation } \\
\text { of IRF3 }\end{array}$ & $\begin{array}{c}\text { miR-200b [126], miR-200c [127], } \\
\text { miR-296-5p [128] } \\
\text { ATRA [129] } \\
\text { KPT-6566 [130] } \\
\text { Juglone [125] }\end{array}$ & $\begin{array}{l}\text { Pre-clinical } \\
\text { FDA-approved in cancer } \\
\text { Pre-clinical } \\
\text { Pre-clinical }\end{array}$ \\
\hline & \multirow[t]{3}{*}{$\begin{array}{l}\text { NFkB and type } \\
\text { I/II IFN pathway }\end{array}$} & STAT3 & $\begin{array}{l}\text { 1. Negative feedback loop of } \\
\text { pro-inflammatory type I signaling } \\
\text { 2. Inhibition of IKK activation }\end{array}$ & $\begin{array}{l}\text { STAT3 inhibitors: } \\
\text { JSI-124 [169] } \\
\text { Indirubin [164] } \\
\text { Resveratrol [165] } \\
\text { Nifuroxazide [170] } \\
\text { Static [166] } \\
\text { Sorafenib [167] } \\
\text { Sunitinib [168] }\end{array}$ & $\begin{array}{c}\text { Pre-clinical } \\
\text { Phase } 3 / 4 \text { trials in acute promyelocytic } \\
\text { leukemia, phase } 2 / 3 \text { in dermatitis and } \\
\text { psoriasis } \\
\text { Phase } 2 / 3 \text { in congestive heart failure, } \\
\text { Friedreich Ataxia, Gulf War Illness, } \\
\text { Lymphangioleiomyomatosis, and } \\
\text { infertility } \\
\text { FDA-approved antibiotic } \\
\text { Pre-clinical } \\
\text { Pre-clinical } \\
\text { Pre-clinical }\end{array}$ \\
\hline & & $\begin{array}{l}\text { EGFR receptor } \\
\text { family } \\
\text { (including } \\
\text { HER2/neu) }\end{array}$ & $\begin{array}{l}\text { 1. STAT1 inactivation } \\
\text { 2. Stimulation of MAPK pathway } \\
\text { 3. STAT3 activation } \\
\text { 4. Fhit degradation }\end{array}$ & $\begin{array}{c}\text { Tyrosine Kinase inhibitors: } \\
\text { EGFR inhibitors (e.g., nimotuzumab } \\
\text { [198], cetuximab [199], afatinib [185], } \\
\text { erlotinib [185], gefitinib [202]). }\end{array}$ & FDA-approved in cancer \\
\hline & & NMYC & $\begin{array}{l}\text { Inhibition of p50 } \\
\text { (although inconsistent) }\end{array}$ & & \\
\hline
\end{tabular}


Table 1. Cont.

\begin{tabular}{|c|c|c|c|c|c|}
\hline Regulation & Pathway & Effector & Described Mechanism(s) & Potential Therapeutic Strategy & Clinical Status \\
\hline & & MAPK pathway & $\begin{array}{l}\text { 1. Decreases IRF1 activity } \\
\text { 2. Decreases STAT1 expression }\end{array}$ & $\begin{array}{c}\text { Tyrosine Kinase inhibitors: } \\
\text { MEK-inhibitors (e.g., trametinib } \\
\text { [188,189], cobimetinib [188], } \\
\text { selumetinib [2]) } \\
\text { BRAF inhibitors (e.g., vemurafenib } \\
\text { [184,190], dabrafenib [41]) }\end{array}$ & $\begin{array}{c}\text { FDA-approved in cancer, selumetinib in } \\
\text { phase } 3 \\
\text { FDA-approved in cancer }\end{array}$ \\
\hline & \multirow{5}{*}{ NFkB pathway } & $\begin{array}{l}\text { NFkB-inducing } \\
\text { receptor } \\
\text { stimulation }\end{array}$ & $\begin{array}{l}\text { 1. TNFR superfamily stimulation } \\
\text { 2. PRR Receptor stimulation } \\
\text { 3. IL-1 receptor stimulation }\end{array}$ & $\mathrm{TNF} \alpha[40]$ & $\begin{array}{l}\text { Phase I-III trials in cancer, all localized } \\
\text { infusions }\end{array}$ \\
\hline & & $\mathrm{IKK} / \mathrm{IkB} \alpha$ & $\begin{array}{l}\text { 1. Boosting IKK-activity } \\
\text { 2. Degradation of IkB } \alpha\end{array}$ & Betulinic acid [45] & Phase I trial, Anxiety \\
\hline & & IKK & Boosting IKK-activity & Calcium/calcineurin + prostratin [51] & Pre-clinical \\
\hline & & Nedd4 & $\begin{array}{l}\text { 1. Degradation of N4BP1 } \\
\text { 2. Degradation of TRAF3 }\end{array}$ & & \\
\hline & & $\begin{array}{l}\text { p50, RelA, and } \\
\text { LMP-2/-7/-10 }\end{array}$ & $\begin{array}{l}\text { 1. Enhanced expression of p50 } \\
\text { 2. Enhanced expression of RelA } \\
\text { 3. Enhances expression of } \\
\text { LMP-2/-7/-10 }\end{array}$ & Retinoids $[41,218]$ & $\begin{array}{l}\text { FDA-approved in several diseases, } \\
\text { including cancers }\end{array}$ \\
\hline & $\begin{array}{l}\text { Type I IFN } \\
\text { pathway }\end{array}$ & $\begin{array}{l}\text { IFN-inducing } \\
\text { receptor } \\
\text { stimulation }\end{array}$ & $\begin{array}{l}\text { 1. PRR Receptors stimulation } \\
\text { (e.g., RNF135, TRIM25, ISG15, } \\
\quad \text { NAB2) } \\
\text { 2. IFNA Receptor stimulation }\end{array}$ & $\begin{array}{c}\text { IFN } \alpha[100,101] \\
\text { IFN } \beta \text { therapy [101] }\end{array}$ & $\begin{array}{l}\text { FDA-approved in hepatitis B \& high-risk } \\
\text { melanoma } \\
\text { Phase III trial in relapsing multiple } \\
\text { sclerosis, Phase I in refractory solid tumors }\end{array}$ \\
\hline & $\begin{array}{l}\text { Type II IFN } \\
\text { pathway }\end{array}$ & $\begin{array}{l}\text { IFN-inducing } \\
\text { receptor } \\
\text { stimulation }\end{array}$ & IFNG Receptor stimulation & $\begin{array}{c}\text { IFN } \gamma \text {-1b } \\
\text { NK cell therapy }[19,33,103,106,107,219]\end{array}$ & $\begin{array}{l}\text { FDA approved as localized injection in } \\
\text { chronic granulomatous disease (CGD) and } \\
\text { severe, malignant ostepetrosis (SMO), } \\
\text { phase I-III in cancers } \\
\text { Phase I/II Trial in several cancer types }\end{array}$ \\
\hline & $\begin{array}{l}\text { NFkB- and type I } \\
\text { IFN pathway }\end{array}$ & STING & $\begin{array}{l}\text { 1. Phosphorylation and } \\
\text { activation of RelA } \\
\text { 2. Phosphorylation and } \\
\text { activation of IRF3 }\end{array}$ & STING agonists (e.g., SB 11285 [177]) & $\begin{array}{l}\text { Phase I Trial in patients with advanced } \\
\text { solid tumors }\end{array}$ \\
\hline
\end{tabular}


Table 1. Cont.

\begin{tabular}{|c|c|c|c|c|c|}
\hline Regulation & Pathway & Effector & Described Mechanism(s) & Potential Therapeutic Strategy & Clinical Status \\
\hline & $\begin{array}{l}\text { NFkB- and type I } \\
\text { IFN pathway }\end{array}$ & & $\begin{array}{l}\text { 1. Increasing APM expression } \\
\text { (Calreticulin, TAP2, calnexin) } \\
\text { 2. Enhancing type I IFN signaling } \\
\text { 3. NFkB stabilization } \\
\text { 4. IFN } \beta \text { secretion }\end{array}$ & $\begin{array}{c}\text { Docetaxel [205] } \\
\text { 5-Fluorouracil [206] } \\
\text { Topoisomerase inhibitors (e.g., topotecan } \\
\text { [207,209], irinotecan [208], and } \\
\text { etoposide [207] } \\
\text { Microtubule stabilizers (e.g., paclitaxel } \\
\text { [207,209] and vinblastine [207]) } \\
\text { Cisplatin [207] }\end{array}$ & All FDA-approved in cancer \\
\hline $\begin{array}{l}\text { Epigenetic } \\
\text { modification }\end{array}$ & $\begin{array}{l}\text { NFkB and type } \\
\text { I/II IFN pathway }\end{array}$ & & $\begin{array}{l}\text { 1. Histon acetylation to decrease } \\
\text { genome accessibility } \\
\text { 2. DNA methylation to decrease } \\
\text { genome accessibility }\end{array}$ & $\begin{array}{c}\text { HDAC inhibitors: (e.g., Romidepsin, } \\
\text { Vorinostat [212] and Panobinostat) } \\
\text { [1,211-214] } \\
\text { DNMTis (e.g., 5-azacytidine [212], } \\
\text { Decitabine [54], and Guadecitabine [216]) }\end{array}$ & $\begin{array}{l}\text { All FDA-approved in cancer } \\
\text { FDA approved, Guadecitabine phase II } \\
\text { trials in cancer). }\end{array}$ \\
\hline
\end{tabular}




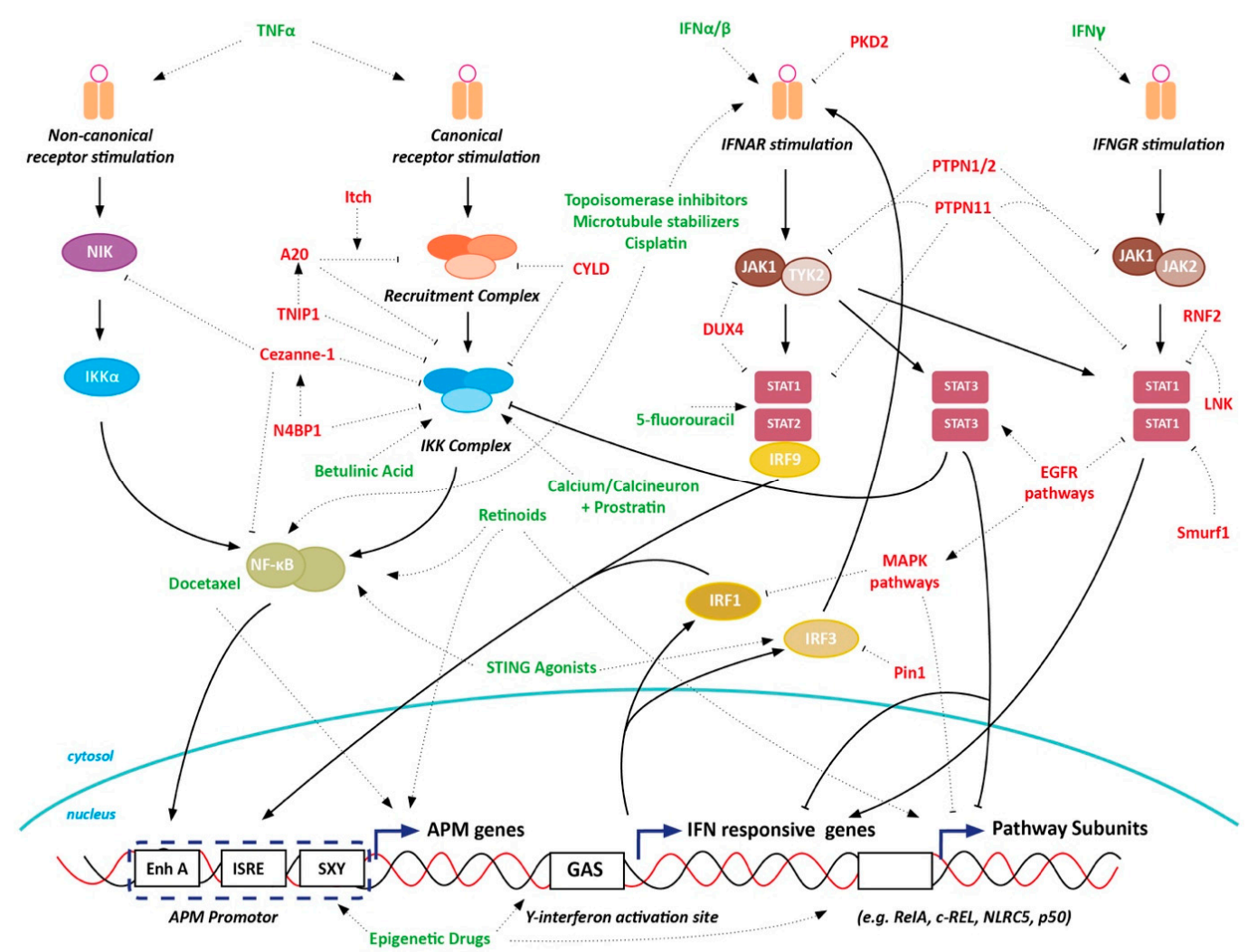

Figure 4. Potential therapeutic interference to boost MHC-I antigen presentation of tumors. Targetable negative pathway regulators are shown in red, (general groups of) compounds positively affecting pathway activation are shown in green.

\section{Conclusions}

In conclusion, MHC-I antigen presentation is a complex process regulated by multiple pathways that can be pharmacologically targeted on multiple levels to increase pathway activation and trigger MHC-I expression in cancer. Increasing antigen presentation in MHC-I-downregulated tumors is key to increase adaptive anti-tumor immunity and improve (immuno)therapy efficacy.

Author Contributions: I.L.M. and A.M.C. performed the literature search and wrote the manuscript with critical comments from S.N. All authors have read and agreed to the published version of the manuscript.

Funding: This research was funded by Villa Joep Foundation, Grant number IWOV-Actief.51381.180034.

Acknowledgments: The authors thank Yvonne van de Grint for designing the figures.

Conflicts of Interest: The authors declare no conflict of interest.

\section{References}

1. Sharma, P.; Hu-Lieskovan, S.; Wargo, J.A.; Ribas, A. Primary, adaptive, and acquired resistance to cancer immunotherapy. Cell 2017, 168, 707-723. [CrossRef] [PubMed]

2. Angell, T.E.; Lechner, M.G.; Jang, J.K.; LoPresti, J.S.; Epstein, A.L. MHC class I loss is a frequent mechanism of immune escape in papillary thyroid cancer that is reversed by interferon and selumetinib treatment in Vitro. Clin. Cancer Res. 2014, 20, 6034-6044. [CrossRef] [PubMed]

3. Mina, M.; Boldrini, R.; Citti, A.; Romania, P.; D'Alicandro, V.; De Ioris, M.; Castellano, A.; Furlanello, C.; Locatelli, F.; Fruci, D. Tumor-infiltrating T lymphocytes improve clinical outcome of therapy-resistant neuroblastoma. Oncoimmunology 2015, 4, 1-14. [CrossRef] [PubMed]

4. Shi, A.H.; Ho, L.-L.; Levine, S.; Yadav, V.; Cheah, J.; Soule, C.; Frederick, D.T.; Liu, D.; Boland, G.; Kellis, M. Epigenomic correlates of checkpoint blockade immunotherapy resistance. Proc. Am. Assoc. Cancer Res. Annu. Meet. 2019, 79. [CrossRef] 
5. Gettinger, S.; Choi, J.; Hastings, K.; Truini, A.; Datar, I.; Sowell, R.; Wurtz, A.; Dong, W.; Cai, G.; Melnick, M.A.; et al. Impaired HLA class I antigen processing and presentation as a mechanism of acquired resistance to immune checkpoint inhibitors in lung cancer. Cancer Discov. 2017, 7, 1420-1435. [CrossRef]

6. Sade-Feldman, M.; Jiao, Y.J.; Chen, J.H.; Rooney, M.S.; Barzily-Rokni, M.; Eliane, J.P.; Bjorgaard, S.L.; Hammond, M.R.; Vitzthum, H.; Blackmon, S.M.; et al. Resistance to checkpoint blockade therapy through inactivation of antigen presentation. Nat. Commun. 2017, 8. [CrossRef]

7. Chowell, D.; Morris, L.G.T.; Grigg, C.M.; Weber, J.K.; Samstein, R.M.; Makarov, V.; Kuo, F.; Kendall, S.M.; Requena, D.; Riaz, N.; et al. Patient HLA class I genotype influences cancer response to checkpoint blockade immunotherapy. Science 2018, 359, 582-587. [CrossRef]

8. Lee, J.H.; Shklovskaya, E.; Lim, S.Y.; Carlino, M.S.; Menzies, A.M.; Stewart, A.; Pedersen, B.; Irvine, M.; Alavi, S.; Yang, J.Y.H.; et al. Transcriptional downregulation of MHC class I and melanoma de- differentiation in resistance to PD-1 inhibition. Nat. Commun. 2020, 11, 1-12. [CrossRef] [PubMed]

9. Benitez, R.; Godelaine, D.; Lopez-Nevot, M.A.; Brasseur, F.; Jiménez, P.; Marchand, M.; Oliva, M.R.; Van Baren, N.; Cabrera, T.; Andry, G.; et al. Mutations of the $\beta 2$-microglobulin gene result in a lack of HLA class I molecules on melanoma cells of two patients immunized with MAGE peptides. Tissue Antigens 1998, 52, 520-529. [CrossRef]

10. Lauss, M.; Donia, M.; Harbst, K.; Andersen, R.; Mitra, S.; Rosengren, F.; Salim, M.; Vallon-Christersson, J.; Törngren, T.; Kvist, A.; et al. Mutational and putative neoantigen load predict clinical benefit of adoptive T cell therapy in melanoma. Nat. Commun. 2017, 8, 1-11. [CrossRef]

11. Khong, H.T.; Wang, Q.J.; Rosenberg, S.A. Identification of multiple antigens recognized by tumor-infiltrating lymphocytes from a single patient: Tumor escape by antigen loss and loss of MHC expression. J. Immunother. 2004, 27, 184-190. [CrossRef] [PubMed]

12. Maleno, I.; López-Nevot, M.; Cabrera, T.; Salinero, J.; Garrido, F. Multiple mechanisms generate HLA class I altered phenotypes in laryngeal carcinomas: High frequency of HLA haplotype loss associated with loss of heterozygosity in chromosome region 6p21. Cancer Immunol. Immunother. 2002, 51, 389-396. [CrossRef]

13. Maleno, I.; Cabrera, C.M.; Cabrera, T.; Paco, L.; López-Nevot, M.A.; Collado, A.; Ferrón, A.; Garrido, F. Distribution of HLA class I altered phenotypes in colorectal carcinomas: High frequency of HLA haplotype loss associated with loss of heterozygosity in chromosome region 6p21. Immunogenetics 2004, 56, 244-253. [CrossRef] [PubMed]

14. Maleno, I.; Romero, J.M.; Cabrera, T.; Paco, L.; Aptsiauri, N.; Cozar, J.M.; Tallada, M.; López-Nevot, M.A.; Garrido, F. LOH at 6p21.3 region and HLA class altered phenotypes in bladder carcinomas. Immunogenetics 2006, 58, 503-510. [CrossRef]

15. Feenstra, M.; Veltkamp, M.; Van Kuik, J.; Wiertsema, S.; Slootweg, P.; Van den Tweel, J.; De Weger, R.; Tilanus, M. HLA class 1 expression and chromosomal deletions at $6 \mathrm{p}$ and $15 \mathrm{q}$ in head and neck squamous cell carcinomas. Tissue Antigens 1999, 54, 235-245. [CrossRef] [PubMed]

16. Garrido, M.A.; Rodriguez, T.; Zinchenko, S.; Maleno, I.; Ruiz-Cabello, F.; Concha, Á.; Olea, N.; Garrido, F.; Aptsiauri, N. HLA class I alterations in breast carcinoma are associated with a high frequency of the loss of heterozygosity at chromosomes 6 and 15. Immunogenetics 2018, 70, 647-659. [CrossRef]

17. Seliger, B.; Ritz, U.; Bock, M.; Huber, C.; Abele, R.; Tampé, R.; Sutter, G.; Sutter, G.; Drexler, I.; Ferrone, S. Immune escape of melanoma: First evidence of structural alterations in two distinct components of the MHC class I antigen processing pathway. Cancer Res. 2001, 61, 8647-8650.

18. Meissner, M.; Reichert, T.E.; Kunkel, M.; Gooding, W.; Whiteside, T.L.; Ferrone, S.; Seliger, B. Defects in the human leukocyte antigen class I antigen-processing machinery in head and neck squamous cell carcinoma: Association with clinical outcome. Clin. Cancer Res. 2005, 11, 2552-2560. [CrossRef]

19. Spel, L.; Boelens, J.J.; Van Der Steen, D.M.; Blokland, N.J.G.; van Noesel, M.M.; Molenaar, J.J.; Heemskerk, M.H.M.; Boes, M.; Nierkens, S. Natural killer cells facilitate PRAME-specific T-cell reactivity against neuroblastoma. Oncotarget 2015, 6, 35770-35781. [CrossRef]

20. Romero, J.M.; Jiménez, P.; Cabrera, T.; Cózar, J.M.; Pedrinaci, S.; Tallada, M.; Garrido, F.; Ruiz-Cabello, F. Coordinated downregulation of the antigen presentation machinery and HLA class I/ $\beta 2$-microglobulin complex is responsible for HLA-ABC loss in bladder cancer. Int. J. Cancer 2005, 113, 605-610. [CrossRef]

21. Squire, R.; Fowler, C.L.; Brooks, S.P.; Rich, G.A.; Cooney, D.R. The relationship of class I MHC antigen expression to stage IV-S disease and survival in neuroblastoma. J. Pediatr. Surg. 1990, 25, 381-386. [CrossRef] 
22. Watson, N.F.S.; Ramage, J.M.; Madjd, Z.; Spendlove, I.; Ellis, I.O.; Scholefield, J.H.; Durrant, L.G. Immunosurveillance is active in colorectal cancer as downregulation but not complete loss of MHC class I expression correlates with a poor prognosis. Int. J. Cancer 2006, 118, 6-10. [CrossRef] [PubMed]

23. Turcotte, S.; Katz, S.C.; Shia, J.; Jarnagin, W.R.; Kingham, T.P.; Allen, P.J.; Fong, Y.; D'Angelica, M.I.; DeMatteo, R.P. Tumor MHC class I expression improves the prognostic value of T-cell density in resected colorectal liver metastases. Cancer Immunol. Res. 2014, 2, 530-537. [CrossRef]

24. Andersson, E.; Villabona, L.; Bergfeldt, K.; Carlson, J.W.; Ferrone, S.; Kiessling, R.; Seliger, B.; Masucci, G.V. Correlation of HLA-A02* genotype and HLA class I antigen down-regulation with the prognosis of epithelial ovarian cancer. Cancer Immunol. Immunother. 2012, 61, 1243-1253. [CrossRef] [PubMed]

25. Roemer, M.G.M.; Advani, R.H.; Redd, R.A.; Pinkus, G.S.; Natkunam, Y.; Ligon, A.H.; Connelly, C.F.; Pak, C.J.; Carey, C.D.; Daadi, S.E.; et al. Classical Hodgkin lymphoma with reduced $\beta 2 \mathrm{M} / \mathrm{MHC}$ class i expression is associated with inferior outcome independent of 9p24.1 status. Cancer Immunol. Res. 2016, 4, 910-916. [CrossRef]

26. Van Houdt, I.S.; Sluijter, B.J.R.; Moesbergen, L.M.; Vos, W.M.; De Gruijl, T.D.; Molenkamp, B.G.; Van Den Eertwegh, A.J.M.; Hooijberg, E.; Van Leeuwen, P.A.M.; Meijer, C.J.L.M.; et al. Favorable outcome in clinically stage II melanoma patients is associated with the presence of activated tumor infiltrating T-lymphocytes and preserved MHC class I antigen expression. Int. J. Cancer 2008, 123, 609-615. [CrossRef]

27. Simpson, J.A.D.; Al-Attar, A.; Watson, N.F.S.; Scholefield, J.H.; Ilyas, M.; Durrant, L.G. Intratumoral T cell infiltration, MHC class I and STAT1 as biomarkers of good prognosis in colorectal cancer. Gut 2010, 59, 926-933. [CrossRef] [PubMed]

28. Inoue, M.; Mimura, K.; Izawa, S.; Shiraishi, K.; Inoue, A.; Shiba, S.; Watanabe, M.; Maruyama, T.; Kawaguchi, Y.; Inoue, S.; et al. Expression of mhc class i on breast cancer cells correlates inversely with her2 expression. Oncoimmunology 2012, 1, 1104-1110. [CrossRef]

29. Hanagiri, T.; Shigematsu, Y.; Kuroda, K.; Baba, T.; Shiota, H.; Ichiki, Y.; Nagata, Y.; Yasuda, M.; Uramoto, H.; So, T.; et al. Prognostic implications of human leukocyte antigen class i expression in patients who underwent surgical resection for non-small-cell lung cancer. J. Surg. Res. 2013, 181, e57-e63. [CrossRef]

30. Spel, L.; Schiepers, A.; Boes, M. NFkB and MHC-1 interplay in neuroblastoma and immunotherapy. Trends Cancer 2018, 4, 715-717. [CrossRef]

31. Anfossi, N.; André, P.; Guia, S.; Falk, C.S.; Roetynck, S.; Stewart, C.A.; Breso, V.; Frassati, C.; Reviron, D.; Middleton, D.; et al. Human NK Cell Education by Inhibitory Receptors for MHC Class, I. Immunity 2006, 25, 331-342. [CrossRef] [PubMed]

32. Lee, J.-C.; Lee, K.-M.; Kim, D.-W.; Heo, D.S. Elevated TGF- $\beta 1$ Secretion and Down-Modulation of NKG2D Underlies Impaired NK Cytotoxicity in Cancer Patients. J. Immunol. 2004, 172, 7335-7340. [CrossRef] [PubMed]

33. Jonges, L.E.; Giezeman-Smits, K.M.; Van Vlierberghe, R.L.E.; Ensink, N.G.; Hagenaars, M.; Joly, É.; Eggermont, A.M.M.; Van de Velde, C.J.H.; Fleuren, G.J.; Kuppen, P.J.K. NK cells modulate MHC class I expression on tumor cells and their susceptibility to lysis. Immunobiology 2000, 202, 326-338. [CrossRef]

34. Jongsma, M.L.M.; Guarda, G.; Spaapen, R.M. The regulatory network behind MHC class I expression. Mol. Immunol. 2019, 113, 16-21. [CrossRef] [PubMed]

35. Lorenzi, S.; Forloni, M.; Cifaldi, L.; Antonucci, C.; Citti, A.; Boldrini, R.; Pezzullo, M.; Castellano, A.; Russo, V.; van der Bruggen, P.; et al. IRF1 and NF-kB Restore MHC Class I-Restricted Tumor Antigen Processing and Presentation to Cytotoxic T Cells in Aggressive Neuroblastoma. PLoS ONE 2012, 7, 1-8. [CrossRef]

36. Sun, S.C. The non-canonical NF-kB pathway in immunity and inflammation. Nat. Rev. Immunol. 2017, 17, 545-558. [CrossRef]

37. Chaturvedi, M.M.; Sung, B.; Yadav, V.R.; Kannappan, R.; Aggarwal, B.B. NF-кB addiction and its role in cancer: One size does not fit all. Oncogene 2011, 30, 1615-1630. [CrossRef]

38. Wells, K.; Hintzsche, J.; Amato, C.M.; Tobin, R.; Vorwald, V.; McCarter, M.; Shellman, Y.; Tan, A.C.; Robinson, W. Investigating the role of NF- $\kappa B$ signaling and immune checkpoint blockade therapy in melanoma. Clin. Res. 2019, 90, abstract 5002.

39. Ea, C.K.; Deng, L.; Xia, Z.P.; Pineda, G.; Chen, Z.J. Activation of IKK by TNF $\alpha$ Requires Site-Specific Ubiquitination of RIP1 and Polyubiquitin Binding by NEMO. Mol. Cell 2006, 22, 245-257. [CrossRef]

40. Cai, W.; Kerner, Z.J.; Sun, J. Targeted Cancer Therapy with Tumor Necrosis Factor-Alpha. Biochem. Insights 2008, 15-21. [CrossRef] 
41. Segars, J.H.; Nagata, T.; Bours, V.; Medin, J.A.; Franzoso, G.; Blanco, J.C.; Drew, P.D.; Becker, K.G.; An, J.; Tang, T. Retinoic acid induction of major histocompatibility complex class I genes in NTera-2 embryonal carcinoma cells involves induction of NF-kappa B (p50-p65) and retinoic acid receptor beta-retinoid X receptor beta heterodimers. Mol. Cell. Biol. 1993, 13, 6157-6169. [CrossRef] [PubMed]

42. Farina, A.R.; Masciulli, M.P.; Tacconelli, A.; Cappabianca, L.; De Santis, G.; Gulino, A.; Mackay, A.R. All-trans-retinoic acid induces nuclear factor $\mathrm{\kappa B}$ activation and matrix metalloproteinase-9 expression and enhances basement membrane invasivity of differentiation-resistant human SK-N-BE 9N neuroblastoma cells. Cell Growth Differ. 2002, 13, 343-354. [PubMed]

43. Vertuani, S.; De Geer, A.; Levitsky, V.; Kogner, P.; Kiessling, R.; Levitskaya, J. Retinoids Act as Multistep Modulators of the Major Histocompatibility Class I Presentation Pathway and Sensitize Neuroblastomas to Cytotoxic Lymphocytes. Cancer Res. 2003, 63, 8006-8013.

44. Matthay, K.K.; Reynolds, C.P.; Seeger, R.C.; Shimada, H.; Adkins, E.S.; Haas-Kogan, D.; Gerbing, R.B.; London, W.B.; Villablanca, J.G. Long-term results for children with high-risk neuroblastoma treated on a randomized trial of myeloablative therapy followed by 13-cis-retinoic acid: A children's oncology group study. J. Clin. Oncol. 2009, 27, 1007-1013. [CrossRef] [PubMed]

45. Kasperczyk, H.; La Ferla-Brühl, K.; Westhoff, M.A.; Behrend, L.; Zwacka, R.M.; Debatin, K.M.; Fulda, S. Betulinic acid as new activator of NF-кB: Molecular mechanisms and implications for cancer therapy. Oncogene 2005, 24, 6945-6956. [CrossRef]

46. Selzer, E.; Pimentel, E.; Wacheck, V.; Schlegel, W.; Pehamberger, H.; Jansen, B.; Kodym, R. Effects of betulinic acid alone and in combination with irradiation in human melanoma cells. J. Invest. Dermatol. 2000, 114, 935-940. [CrossRef]

47. Wick, W.; Grimmel, C.; Wagenknecht, B.; Dichgans, J.; Weller, M. Betulinic acid-induced apoptosis in glioma cells: A sequential requirement for new protein synthesis, formation of reactive oxygen species, and caspase processing. J. Pharmacol. Exp. Ther. 1999, 289, 1306-1312.

48. Fulda, S.; Friesen, C.; Los, M.; Scaffidi, C.; Mier, W.; Benedict, M.; Nuñez, G.; Krammer, P.H.; Peter, M.E.; Debatin, K.M. Betulinic acid triggers CD95 (APO-1/Fas)- and p53-independent apoptosis via activation of caspases in neuroectodermal tumors. Cancer Res. 1997, 57, 4956-4964. [PubMed]

49. Chowdhury, A.R.; Suparna, M.; Mittra, B.; Sharma, S.; Mukhopadhyay, S.; Majumder, H.K. Betulinic acid, a potent inhibitor of eukaryotic topoisomerase I: Identification of the inhibitory step, the major functional group responsible and development of more potent derivatives. Med. Sci. Monit. 2002, 8, 254-261.

50. Kwon, H.J.; Shim, J.S.; Kim, J.H.; Cho, H.Y.; Yum, Y.N.; Kim, S.H.; Yu, J. Betulinic acid inhibits growth factor-induced in vitro angiogenesis via the modulation of mitochondrial function in endothelial cells. Japanese J. Cancer Res. 2002, 93, 417-425. [CrossRef]

51. Chan, J.K.; Bhattacharyya, D.; Lassen, K.G.; Ruelas, D.; Greene, W.C. Calcium/calcineurin synergizes with prostratin to promote NF-kB dependent activation of latent HIV. PLoS ONE 2013, 8, e77749. [CrossRef] [PubMed]

52. Fang, D.F.; He, K.; Wang, N.; Sang, Z.H.; Qiu, X.; Xu, G.; Jian, Z.; Liang, B.; Li, T.; Li, H.Y.; et al. NEDD4 ubiquitinates TRAF3 to promote CD40-mediated AKT activation. Nat. Commun. 2014, 5, 1-11. [CrossRef] [PubMed]

53. Oberst, A.; Malatesta, M.; Aqeilan, R.I.; Rossi, M.; Salomoni, P.; Murillas, R.; Sharma, P.; Kuehn, M.R.; Oren, M.; Croce, C.M.; et al. The Nedd4-binding partner 1 (N4BP1) protein is an inhibitor of the E3 ligase Itch. Proc. Natl. Acad. Sci. USA 2007, 104, 11280-11285. [CrossRef]

54. Spel, L.; Nieuwenhuis, J.; Haarsma, R.; Stickel, E.; Bleijerveld, O.B.; Altelaar, M.; Boelens, J.J.; Brummelkamp, T.R.; Nierkens, S.; Boes, M. Nedd4-binding protein 1 and TNFAIP3-interacting protein 1 control MHC-1 display in neuroblastoma. Cancer Res. 2018, 78, 6621-6631. [CrossRef] [PubMed]

55. Fenner, B.J.; Scannell, M.; Prehn, J.H.M. Identification of polyubiquitin binding proteins involved in NF- $\mathrm{kB}$ signaling using protein arrays. Biochim. Biophys. Acta Proteins Proteomics 2009, 1794, 1010-1016. [CrossRef] [PubMed]

56. Nepravishta, R.; Ferrentino, F.; Mandaliti, W.; Mattioni, A.; Weber, J.; Polo, S.; Castagnoli, L.; Cesareni, G.; Paci, M.; Santonico, E. CoCUN, a novel ubiquitin binding domain identified in N4BP1. Biomolecules 2019, 9, 284. [CrossRef] 
57. Hu, H.; Brittain, G.C.; Chang, J.H.; Puebla-Osorio, N.; Jin, J.; Zal, A.; Xiao, Y.; Cheng, X.; Chang, M.; Fu, Y.X.; et al. OTUD7B controls non-canonical NF-kB activation through deubiquitination of TRAF3. Nature 2013, 494, 371-374. [CrossRef] [PubMed]

58. Yang, X.D.; Sun, S.C. Targeting signaling factors for degradation, an emerging mechanism for TRAF functions. Immunol. Rev. 2015, 266, 56-71. [CrossRef]

59. G'Sell, R.T.; Gaffney, P.M.; Powell, D.W. A20-binding inhibitor of NF- $k B$ activation 1 is a physiologic inhibitor of NF-кB: A molecular switch for inflammation and autoimmunity. Arthritis Rheumatol. 2015, 67, 2292-2302. [CrossRef]

60. Wagner, S.; Carpentier, I.; Rogov, V.; Kreike, M.; Ikeda, F.; Löhr, F.; Wu, C.J.; Ashwell, J.D.; Dötsch, V.; Dikic, I.; et al. Ubiquitin binding mediates the NF-KB inhibitory potential of ABIN proteins. Oncogene 2008, 27, 3739-3745. [CrossRef]

61. Cohen, S.; Ciechanover, A.; Kravtsova-Ivantsiv, Y.; Lapid, D.; Lahav-Baratz, S. ABIN-1 negatively regulates NF-kB by inhibiting processing of the p105 precursor. Biochem. Biophys. Res. Commun. 2009, 389, 205-210. [CrossRef] [PubMed]

62. Mauro, C.; Pacifico, F.; Lavorgna, A.; Mellone, S.; Iannetti, A.; Acquaviva, R.; Formisano, S.; Vito, P.; Leonardi, A. ABIN-1 binds to NEMO/IKK $\gamma$ and co-operates with A20 in inhibiting NF-KB. J. Biol. Chem. 2006, 281, 18482-18488. [CrossRef] [PubMed]

63. Cruz, J.A.; Childs, E.E.; Amatya, N.; Garg, A.V.; Beyaert, R.; Kane, L.P.; Aneskievich, B.J.; Ma, A.; Gaffen, S.L. IL-17 Signaling Triggers Degradation of the Constitutive NF-кB Inhibitor ABIN-1. ImmunoHorizons 2017, 1, 133-141. [CrossRef] [PubMed]

64. Yang, B.; Kang, H.; Fung, A.; Zhao, H.; Wang, T.; Ma, D. The role of interleukin 17 in tumour proliferation, angiogenesis, and metastasis. Mediators Inflamm. 2014, 2014. [CrossRef] [PubMed]

65. Wu, W.; He, K.; Guo, Q.; Chen, J.; Zhang, M.; Huang, K.; Yang, D.; Wu, L.; Deng, Y.; Luo, X.; et al. SSRP1 promotes colorectal cancer progression and is negatively regulated by miR-28-5p. J. Cell. Mol. Med. 2019, 23, 3118-3129. [CrossRef]

66. Wang, C.; Wu, C.; Yang, Q.; Ding, M.; Zhong, J.; Zhang, C.Y.; Ge, J.; Wang, J.; Zhang, C. miR-28-5p acts as a tumor suppressor in renal cell carcinoma for multiple antitumor effects by targeting RAP1B. Oncotarget 2016, 7, 73888-73902. [CrossRef]

67. Shi, X.; Teng, F. Down-regulated miR-28-5p in human hepatocellular carcinoma correlated with tumor proliferation and migration by targeting insulin-like growth factor-1 (IGF-1). Mol. Cell. Biochem. 2015, 408, 283-293. [CrossRef]

68. Song, L.; Lin, C.; Gong, H.; Wang, C.; Liu, L.; Wu, J.; Tao, S.; Hu, B.; Cheng, S.Y.; Li, M.; et al. MiR-486 sustains

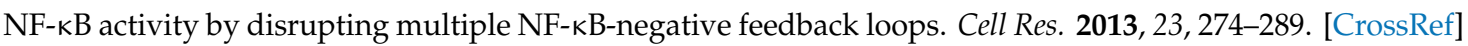

69. Tan, G.; Wu, L.; Tan, J.; Zhang, B.; Tai, W.C.S.; Xiong, S.; Chen, W.; Yang, J.; Li, H. MIR-1180 promotes apoptotic resistance to human hepatocellular carcinoma via activation of NF-kB signaling pathway. Sci. Rep. 2016, 6, 1-11. [CrossRef]

70. Xu, J.; Jiang, N.; Shi, H.; Zhao, S.; Yao, S.; Shen, H. MiR-28-5p promotes the development and progression of ovarian cancer through inhibition of N4BP1. Int. J. Oncol. 2017, 50, 1383-1391. [CrossRef]

71. Zhu, G.; Wang, Z.; Mijiti, M.; Du, G.; Li, Y.; Dangmurenjiafu, G. MiR-28-5p promotes human glioblastoma cell growth through inactivation of FOXO1. Int. J. Clin. Exp. Pathol. 2019, 12, 2972-2980. [PubMed]

72. Shembade, N.; Harhaj, E.W. Regulation of NF-kB signaling by the A20 deubiquitinase. Cell. Mol. Immunol. 2012, 9, 123-130. [CrossRef] [PubMed]

73. Wertz, I.E.; Rourke, K.M.O.; Zhou, H.; Eby, M.; Aravind, L.; Seshagiri, S.; Wu, P.; Wiesmann, C.; Dixit, V.M. ligase domains of A20 downregulate NF- k B signalling. Nature 2004, 430, 1-6. [CrossRef]

74. Shembade, N.; Harhaj, N.S.; Parvatiyar, K.; Copeland, N.G.; Jenkins, N.A.; Matesic, L.E.; Harhaj, E.W. The E3 ligase Itch negatively regulates inflammatory signaling pathways by controlling the function of the ubiquitin-editing enzyme A20. Nat. Immunol. 2008, 9, 254-262. [CrossRef]

75. Ishihara, T.; Tsuda, H.; Hotta, A.; Kozaki, K.I.; Yoshida, A.; Noh, J.Y.; Ito, K.; Imoto, I.; Inazawa, J. ITCH is a putative target for a novel 20q11.22 amplification detected in anaplastic thyroid carcinoma cells by array-based comparative genomic hybridization. Cancer Sci. 2008, 99, 1940-1949. [CrossRef] [PubMed]

76. Ho, K.C.; Zhou, Z.; She, Y.M.; Chun, A.; Cyr, T.D.; Yang, X. Itch E3 ubiquitin ligase regulates large tumor suppressor 1 tumor-suppressor stability. Proc. Natl. Acad. Sci. USA 2011, 108, 4870-4875. [CrossRef] [PubMed] 
77. Salah, Z.; Melino, G.; Aqeilan, R.I. Negative regulation of the Hippo pathway by E3 ubiquitin ligase ITCH is sufficient to promote tumorigenicity. Cancer Res. 2011, 71, 2010-2020. [CrossRef]

78. Salah, Z.; Itzhaki, E.; Aqeilan, R.I. The ubiquitin E3 ligase ITCH enhances breast tumor progression by inhibiting the Hippo tumor suppressor pathway. Oncotarget 2014, 5, 10886-10900. [CrossRef]

79. Meng, J.; Tagalakis, A.D.; Hart, S.L. Silencing E3 Ubiqutin ligase ITCH as a potential therapy to enhance chemotherapy efficacy in p53 mutant neuroblastoma cells. Sci. Rep. 2020, 10, 1-12. [CrossRef]

80. Rossi, M.; Rotblat, B.; Ansell, K.; Amelio, I.; Caraglia, M.; Misso, G.; Bernassola, F.; Cavasotto, C.N.; Knight, R.A.; Ciechanover, A.; et al. High throughput screening for inhibitors of the HECT ubiquitin E3 ligase ITCH identifies antidepressant drugs as regulators of autophagy. Cell Death Dis. 2014, 5, 1-12. [CrossRef]

81. Liu, Y.M.; HuangFu, W.C.; Huang, H.L.; Wu, W.C.; Chen, Y.L.; Yen, Y.; Huang, H.L.; Nien, C.Y.; Lai, M.J.; Pan, S.L.; et al. 1,4-Naphthoquinones as inhibitors of Itch, a HECT domain-E3 ligase, and tumor growth suppressors in multiple myeloma. Eur. J. Med. Chem. 2017, 140, 84-91. [CrossRef] [PubMed]

82. Zhu, J.; Bengtsson, B.O.; Mix, E.; Thorell, L.H.; Olsson, T.; Link, H. Effect of monoamine reuptake inhibiting antidepressants on major histocompatibility complex expression on macrophages in normal rats and rats with experimental allergic neuritis (EAN). Immunopharmacology 1994, 27, 225-244. [CrossRef]

83. Kovalenko, A.; Chable-Bessia, C.; Cantarella, G.; Israël, A.; Wallach, D.; Courtois, G. The tumour suppressor CYLD negatively regulates NF- $\mathrm{B}$ signalling by deubiquitination. Nature 2003, 424, 801-805. [CrossRef] [PubMed]

84. Yin, J.; Weng, C.; Ma, J.; Chen, F.; Huang, Y.; Feng, M. MicroRNA-1288 promotes cell proliferation of human glioblastoma cells by repressing ubiquitin carboxyl-terminal hydrolase CYLD expression. Mol. Med. Rep. 2017, 16, 6764-6770. [CrossRef] [PubMed]

85. Qiu, H.; Yuan, S.; Lu, X. miR-186 suppressed CYLD expression and promoted cell proliferation in human melanoma. Oncol. Lett. 2016, 12, 2301-2306. [CrossRef] [PubMed]

86. Ni, F.; Zhao, H.; Cui, H.; Wu, Z.; Chen, L.; Hu, Z.; Guo, C.; Liu, Y.; Chen, Z.; Wang, X.; et al. MicroRNA-362-5p promotes tumor growth and metastasis by targeting CYLD in hepatocellular carcinoma. Cancer Lett. 2015, 356, 809-818. [CrossRef] [PubMed]

87. Farshi, P.; Deshmukh, R.R.; Nwankwo, J.O.; Arkwright, R.T.; Cvek, B.; Liu, J.; Dou, Q.P. Deubiquitinases (DUBs) and DUB inhibitors: A patent review. Expert Opin. Ther. Pat. 2015, 25, 1191-1208. [CrossRef]

88. Sun, S.C. CYLD: A tumor suppressor deubiquitinase regulating NF-B activation and diverse biological processes. Cell Death Differ. 2010, 17, 25-34. [CrossRef]

89. Wang, J.H.; Wei, W.; Guo, Z.X.; Shi, M.; Guo, R. Decreased Cezanne expression is associated with the progression and poor prognosis in hepatocellular carcinoma. J. Transl. Med. 2015, 13, 1-10. [CrossRef]

90. Tilborghs, S.; Corthouts, J.; Verhoeven, Y.; Arias, D.; Rolfo, C.; Trinh, X.B.; van Dam, P.A. The role of Nuclear Factor-kappa B signaling in human cervical cancer. Crit. Rev. Oncol. Hematol. 2017, 120, 141-150. [CrossRef]

91. Musella, M.; Manic, G.; De Maria, R.; Vitale, I.; Sistigu, A. Type-I-interferons in infection and cancer: Unanticipated dynamics with therapeutic implications. Oncoimmunology 2017, 6, 1-12. [CrossRef]

92. Castro, F.; Cardoso, A.P.; Gonçalves, R.M.; Serre, K.; Oliveira, M.J. Interferon-gamma at the crossroads of tumor immune surveillance or evasion. Front. Immunol. 2018, 9, 1-19. [CrossRef] [PubMed]

93. Zaretsky, J.M.; Garcia-Diaz, A.; Shin, D.S.; Escuin-Ordinas, H.; Hugo, W.; Hu-Lieskovan, S.; Torrejon, D.Y.; Abril-Rodriguez, G.; Sandoval, S.; Barthly, L.; et al. Mutations associated with acquired resistance to PD-1 blockade in melanoma. N. Engl. J. Med. 2016, 375, 819-829. [CrossRef] [PubMed]

94. Gao, J.; Shi, L.Z.; Zhao, H.; Chen, J.; Xiong, L.; He, Q.; Chen, T.; Roszik, J.; Bernatchez, C.; Woodman, S.E.; et al. Loss of IFN- $\gamma$ Pathway Genes in Tumor Cells as a Mechanism of Resistance to Anti-CTLA-4 Therapy. Cell 2016, 167, 397-404.e9. [CrossRef] [PubMed]

95. Stelloo, E.; Versluis, M.A.; Nijman, H.W.; De Bruyn, M.; Plat, A.; Osse, E.M.; Van Dijk, R.H.; Nout, R.A.; Creutzberg, C.L.; De Bock, G.H.; et al. Microsatellite instability derived JAK1 frameshift mutations are associated with tumor immune evasion in endometrioid endometrial cancer. Oncotarget 2016, 7, 39885-39893. [CrossRef]

96. Smithy, J.W.; Moore, L.M.; Pelekanou, V.; Rehman, J.; Gaule, P.; Wong, P.F.; Neumeister, V.M.; Sznol, M.; Kluger, H.M.; Rimm, D.L. Nuclear IRF-1 expression as a mechanism to assess "Capability" to express PD-L1 and response to PD-1 therapy in metastatic melanoma. J. Immunother. Cancer 2017, 5, 1-9. [CrossRef] 
97. Bhat, M.Y.; Solanki, H.S.; Advani, J.; Khan, A.A.; Keshava Prasad, T.S.; Gowda, H.; Thiyagarajan, S.; Chatterjee, A. Comprehensive network map of interferon gamma signaling. J. Cell Commun. Signal. 2018, 12, 745-751. [CrossRef]

98. Ivashkiv, L.B.; Donlin, L.T. Regulation of type i interferon responses. Nat. Rev. Immunol. 2014, 14, 36-49. [CrossRef]

99. Propper, D.J.; Chao, D.; Braybrooke, J.P.; Bahl, P.; Thavasu, P.; Balkwill, F.; Turley, H.; Dobbs, N.; Gatter, K.; Talbot, D.C.; et al. Low-Dose IFN- $\gamma$ Induces Tumor MHC Expression in Metastatic Malignant Melanoma. Clin. Cancer Res. 2003, 9, 84-92.

100. Yang, I.; Kremen, T.J.; Giovannone, A.J.; Paik, E.; Odesa, S.K.; Prins, R.M.; Liau, L.M. Modulation of major histocompatibility complex Class I molecules and major histocompatibility complex-bound immunogenic peptides induced by interferon- $\alpha$ and interferon- $\gamma$ treatment of human glioblastoma multiforme. J. Neurosurg. 2004, 100, 310-319. [CrossRef]

101. George, P.M.; Badiger, R.; Alazawi, W.; Foster, G.R.; Mitchell, J.A. Pharmacology and therapeutic potential of interferons. Pharmacol. Ther. 2012, 135, 44-53. [CrossRef] [PubMed]

102. Hemmerle, T.; Neri, D. The dose-dependent tumor targeting of antibody-IFN $\gamma$ fusion proteins reveals an unexpected receptor-trapping mechanism in vivo. Cancer Immunol. Res. 2014, 2, 559-567. [CrossRef]

103. Yang, Y.; Lim, O.; Kim, T.M.; Ahn, Y.O.; Choi, H.; Chung, H.; Min, B.; Her, J.H.; Cho, S.Y.; Keam, B.; et al. Phase I study of random healthy donor-derived allogeneic natural killer cell therapy in patients with malignant lymphoma or advanced solid tumors. Cancer Immunol. Res. 2016, 4, 215-224. [CrossRef] [PubMed]

104. Cho, Y.-H.; Choi, M.G.; Kim, D.H.; Choi, Y.J.; Kim, S.Y.; Sung, K.J.; Lee, J.C.; Kim, S.-Y.; Rho, J.K.; Choi, C.M. Natural Killer Cells as a Potential Biomarker for Predicting Immunotherapy Efficacy in Patients with Non-Small Cell Lung Cancer. Target. Oncol. 2020, 15, 241-247. [CrossRef] [PubMed]

105. Mazzaschi, G.; Facchinetti, F.; Missale, G.; Canetti, D.; Madeddu, D.; Zecca, A.; Veneziani, M.; Gelsomino, F.; Goldoni, M.; Buti, S.; et al. The circulating pool of functionally competent NK and CD8+ cells predicts the outcome of anti-PD1 treatment in advanced NSCLC. Lung Cancer 2019, 127, 153-163. [CrossRef] [PubMed]

106. Castriconi, R.; Dondero, A.; Augugliaro, R.; Cantoni, C.; Carnemolla, B.; Sementa, A.R.; Negri, F.; Conte, R.; Corrias, M.V.; Moretta, L.; et al. Identification of 4Ig-B7-H3 as a neuroblastoma-associated molecule that exerts a protective role from an NK cell-mediated lysis. Proc. Natl. Acad. Sci. USA 2004, 101, 12640-12645. [CrossRef] [PubMed]

107. Lee, Y.H.; Martin-Orozco, N.; Zheng, P.; Li, J.; Zhang, P.; Tan, H.; Park, H.J.; Jeong, M.; Chang, S.H.; Kim, B.S.; et al. Inhibition of the B7-H3 immune checkpoint limits tumor growth by enhancing cytotoxic lymphocyte function. Cell Res. 2017, 27, 1034-1045. [CrossRef]

108. Hu, Y.; Tian, Z.; Zhang, C. Natural Killer Cell-Based Immunotherapy for Cancer: Advances and Prospects. Engineering 2019, 5, 106-114. [CrossRef]

109. Bernson, E.; Hallner, A.; E Sander, F.; Wilsson, O.; Werlenius, O.; Rydström, A.; Kiffin, R.; Brune, M.; Foà, R.; Aurelius, J.; et al. Impact of killer-immunoglobulin-like receptor and human leukocyte antigen genotypes on the efficacy of immunotherapy in acute myeloid leukemia. Leuk. 2017, 31, 2552-2559. [CrossRef]

110. Boudreau, J.E.; Giglio, F.; Gooley, T.A.; Stevenson, P.A.; Le Luduec, J.-B.; Shaffer, B.C.; Rajalingam, R.; Hou, L.; Hurley, C.K.; Noreen, H.; et al. KIR3DL1/HLA-B Subtypes Govern Acute Myelogenous Leukemia Relapse After Hematopoietic Cell Transplantation. J. Clin. Oncol. 2017, 35, 2268-2278. [CrossRef]

111. Lupo, K.B.; Matosevic, S. Natural Killer Cells as Allogeneic Effectors in Adoptive Cancer Immunotherapy. Cancers 2019, 11, 769. [CrossRef] [PubMed]

112. Dondero, A.; Pastorino, F.; Della Chiesa, M.; Corrias, M.V.; Morandi, F.; Pistoia, V.; Olive, D.; Bellora, F.; Locatelli, F.; Castellano, A.; et al. PD-L1 expression in metastatic neuroblastoma as an additional mechanism for limiting immune surveillance. Oncoimmunology 2016, 5, 1-9. [CrossRef] [PubMed]

113. Chen, S.; Crabill, G.A.; Pritchard, T.S.; McMiller, T.L.; Wei, P.; Pardoll, D.M.; Pan, F.; Topalian, S.L. Mechanisms regulating PD-L1 expression on tumor and immune cells. J. Immunother. Cancer 2019, 7, 1-12. [CrossRef] [PubMed]

114. Chew, G.-L.; Campbell, A.E.; De Neef, E.; Sutliff, N.A.; Shadle, S.C.; Tapscott, S.J.; Bradley, R.K. DUX4 Suppresses MHC Class I to Promote Cancer Immune Evasion and Resistance to Checkpoint Blockade. Dev. Cell 2019, 50, 658-671.e7. [CrossRef] 
115. Bosnakovski, D.; da Silva, M.T.; Sunny, S.T.; Ener, E.T.; Toso, E.A.; Yuan, C.; Cui, Z.; Walters, M.A.; Jadhav, A.; Kyba, M. A novel P300 inhibitor reverses DUX4-mediated global histone H3 hyperacetylation, target gene expression, and cell death. Sci. Adv. 2019, 5, eaaw7781. [CrossRef]

116. Lasko, L.M.; Jakob, C.G.; Edalji, R.P.; Qiu, W.; Montgomery, D.; Digiammarino, E.L.; Hansen, T.M.; Risi, R.M.; Frey, R.; Manaves, V.; et al. Discovery of a selective catalytic p300/CBP inhibitor that targets lineage-specific tumours. Nature 2017, 550, 128-132. [CrossRef]

117. Oliva, J.; Galasinski, S.; Richey, A.; Campbell, A.E.; Meyers, M.J.; Modi, N.; Zhong, J.W.; Tawil, R.; Tapscott, S.J.; Sverdrup, F.M. Clinically advanced p38 inhibitors suppress DUX4 expression in cellular and animal models of facioscapulohumeral muscular dystrophys. J. Pharmacol. Exp. Ther. 2019, 370, 219-230. [CrossRef] [PubMed]

118. Yong, H.Y.; Koh, M.S.; Moon, A. The p38 MAPK inhibitors for the treatment of inflammatory diseases and cancer. Expert Opin. Investig. Drugs 2009, 18, 1893-1905. [CrossRef] [PubMed]

119. Ding, L.W.; Sun, Q.Y.; Lin, D.C.; Chien, W.; Hattori, N.; Dong, X.M.; Gery, S.; Garg, M.; Doan, N.B.; Said, J.W.; et al. LNK (SH2B3): Paradoxical effects in ovarian cancer. Oncogene 2015, 34, 1463-1474. [CrossRef] [PubMed]

120. Ding, L.W.; Sun, Q.Y.; Edwards, J.J.; Fernández, L.T.; Ran, X.B.; Zhou, S.Q.; Scolyer, R.A.; Wilmott, J.S.; Thompson, J.F.; Doan, N.; et al. LNK suppresses interferon signaling in melanoma. Nat. Commun. 2019, 10. [CrossRef]

121. Kriegel, A.J.; Baker, M.A.; Liu, Y.; Liu, P.; Cowley, A.W.; Liang, M. Endogenous MicroRNAs in human microvascular endothelial cells regulate mRNAs encoded by hypertension-related genes. Hypertension 2015, 66, 793-799. [CrossRef] [PubMed]

122. Wang, Y.; Jin, B.J.; Chen, Q.; Yan, B.J.; Liu, Z.L. MicroRNA-29b upregulation improves myocardial fibrosis and cardiac function in myocardial infarction rats through targeting SH2B3. Eur. Rev. Med. Pharmacol. Sci. 2019, 23, 10115-10122. [CrossRef]

123. Saitoh, T.; Tun-Kyi, A.; Ryo, A.; Yamamoto, M.; Finn, G.; Fujita, T.; Akira, S.; Yamamoto, N.; Lu, K.P.; Yamaoka, S. Negative regulation of interferon-regulatory factor 3-dependent innate antiviral response by the prolyl isomerase Pin1. Nat. Immunol. 2006, 7, 598-605. [CrossRef]

124. Chen, Y.; Wu, Y.; Yang, H.; Li, X.; Jie, M.; Hu, C.; Wu, Y.; Yang, S.; Yang, Y. Prolyl isomerase Pin1: A promoter of cancer and a target for therapy. Cell Death Dis. 2018, 9. [CrossRef] [PubMed]

125. Hennig, L.; Christner, C.; Kipping, M.; Schelbert, B.; Rücknagel, K.P.; Grabley, S.; Küllertz, G.; Fischer, G. Selective inactivation of parvulin-like peptidyl-prolyl cis/trans isomerases by juglone. Biochemistry 1998, 37, 5953-5960. [CrossRef] [PubMed]

126. Zhang, X.; Zhang, B.; Gao, J.; Wang, X.; Liu, Z. Regulation of the MicroRNA 200b (miRNA-200b) by transcriptional regulators PEA3 and ELK-1 protein affects expression of Pin1 protein to control anoikis. J. Biol. Chem. 2013, 288, 32742-32752. [CrossRef]

127. Luo, M.L.; Gong, C.; Chen, C.H.; Lee, D.Y.; Hu, H.; Huang, P.; Yao, Y.; Guo, W.; Reinhardt, F.; Wulf, G.; et al. Prolyl isomerase pin1 acts downstream of mir200c to promote cancer stem-like cell traits in breast cancer. Cancer Res. 2014, 74, 3603-3616. [CrossRef] [PubMed]

128. Lee, K.H.; Lin, F.C.; Hsu, T.I.; Lin, J.T.; Guo, J.H.; Tsai, C.H.; Lee, Y.C.; Lee, Y.C.; Chen, C.L.; Hsiao, M.; et al. MicroRNA-296-5p (miR-296-5p) functions as a tumor suppressor in prostate cancer by directly targeting Pin1. Biochim. Biophys. Acta Mol. Cell Res. 2014, 1843, 2055-2066. [CrossRef] [PubMed]

129. Wei, S.; Kozono, S.; Kats, L.; Nechama, M.; Li, W.; Guarnerio, J.; Luo, M.; You, M.H.; Yao, Y.; Kondo, A.; et al. Active Pin1 is a key target of all-trans retinoic acid in acute promyelocytic leukemia and breast cancer. Nat. Med. 2015, 21, 457-466. [CrossRef] [PubMed]

130. Campaner, E.; Rustighi, A.; Zannini, A.; Cristiani, A.; Piazza, S.; Ciani, Y.; Kalid, O.; Golan, G.; Baloglu, E.; Shacham, S.; et al. A covalent PIN1 inhibitor selectively targets cancer cells by a dual mechanism of action. Nat. Commun. 2017, 8. [CrossRef]

131. Myers, M.P.; Andersen, J.N.; Cheng, A.; Tremblay, M.L.; Horvath, C.M.; Parisien, J.P.; Salmeen, A.; Barford, D.; Tonks, N.K. TYK2 and JAK2 Are Substrates of Protein-tyrosine Phosphatase 1B. J. Biol. Chem. 2001, 276, 47771-47774. [CrossRef] [PubMed]

132. You, M.; Yu, D.-H.; Feng, G.-S. Shp-2 Tyrosine Phosphatase Functions as a Negative Regulator of the Interferon-Stimulated Jak/STAT Pathway. Mol. Cell. Biol. 1999, 19, 2416-2424. [CrossRef] [PubMed]

133. Bollu, L.R.; Mazumdar, A.; Savage, M.I.; Brown, P.H. Molecular pathways: Targeting protein tyrosine phosphatases in cancer. Clin. Cancer Res. 2017, 23, 2136-2142. [CrossRef] [PubMed] 
134. Yi, T.; Pathak, M.K.; Lindner, D.J.; Ketterer, M.E.; Farver, C.; Borden, E.C. Anticancer Activity of Sodium Stibogluconate in Synergy with IFNs. J. Immunol. 2002, 169, 5978-5985. [CrossRef]

135. Lantz, K.A.; Hart, S.G.E.; Planey, S.L.; Roitman, M.F.; Ruiz-White, I.A.; Wolfe, H.R.; McLane, M.P. Inhibition of PTP1B by trodusquemine (MSI-1436) causes fat-specific weight loss in diet-induced obese mice. Obesity 2010, 18, 1516-1523. [CrossRef]

136. Huffaker, T.B.; Lee, S.H.; Tang, W.W.; Wallace, J.A.; Alexander, M.; Runtsch, M.C.; Larsen, D.K.; Thompson, J.; Ramstead, A.G.; Voth, W.P.; et al. Antitumor immunity is defective in T cell-specific microRNA-155- deficient mice and is rescued by immune checkpoint blockade. J. Biol. Chem. 2017, 292, 18530-18541. [CrossRef]

137. Higgs, G.; Slack, F. The multiple roles of microRNA-155 in oncogenesis. J. Clin. Bioinforma. 2013, 3, 1-8. [CrossRef]

138. Liu, B.; Mink, S.; Wong, K.A.; Stein, N.; Getman, C.; Dempsey, P.W.; Wu, H.; Shuai, K. PIAS1 selectively inhibits interferon-inducible genes and is important in innate immunity. Nat. Immunol. 2004, 5, 891-898. [CrossRef]

139. Yuan, C.; Qi, J.; Zhao, X.; Gao, C. Smurf1 protein negatively regulates interferon- $\gamma$ signaling through promoting STAT1 protein ubiquitination and degradation. J. Biol. Chem. 2012, 287, 17006-17015. [CrossRef]

140. Liu, S.; Jiang, M.; Wang, W.; Liu, W.; Song, X.; Ma, Z.; Zhang, S.; Liu, L.; Liu, Y.; Cao, X. Nuclear RNF2 inhibits interferon function by promoting K33-linked STAT1 disassociation from DNA article. Nat. Immunol. 2018, 19, 41-50. [CrossRef]

141. Sánchez-Beato, M.; Sánchez, E.; González-Carreró, J.; Morente, M.; Díez, A.; Sánchez-Verde, L.; Martín, M.C.; Cigudosa, J.C.; Vidal, M.; Piris, M.A. Variability in the expression of polycomb proteins in different normal and tumoral tissues. A pilot study using tissue microarrays. Mod. Pathol. 2006, 19, 684-694. [CrossRef] [PubMed]

142. Romero, I.; Martinez, M.; Garrido, C.; Collado, A.; Algarra, I.; Garrido, F.; Garcia-Lora, A.M. The tumour suppressor Fhit positively regulates MHC class I expression on cancer cells. J. Pathol. 2012, 227, 367-379. [CrossRef] [PubMed]

143. Rai, K.; Akdemir, K.C.; Kwong, L.N.; Fiziev, P.; Wu, C.J.; Keung, E.Z.; Sharma, S.; Samant, N.S.; Williams, M.; Axelrad, J.B.; et al. Dual roles of RNF2 in melanoma progression. Cancer Discov. 2015, 5, 1314-1327. [CrossRef] [PubMed]

144. Rabellino, A.; Andreani, C.; Scaglioni, P.P. The Role of PIAS SUMO E3-Ligases in Cancer. Cancer Res. 2017, 77, 1542-1547. [CrossRef]

145. Yang, H.; Yu, N.; Xu, J.; Ding, X.; Deng, W.; Wu, G.; Li, X.; Hou, Y.; Liu, Z.; Zhao, Y.; et al. SMURF1 facilitates estrogen receptor a signaling in breast cancer cells. J. Exp. Clin. Cancer Res. 2018, 37, 1-12. [CrossRef] [PubMed]

146. Chen, X.; Chen, S.; Li, Y.; Gao, Y.; Huang, S.; Li, H.; Zhu, Y. SMURF1-mediated ubiquitination of ARHGAP26 promotes ovarian cancer cell invasion and migration. Exp. Mol. Med. 2019, 51. [CrossRef]

147. Nair, S.; Bist, P.; Dikshit, N.; Krishnan, M.N. Global functional profiling of human ubiquitome identifies E3 ubiquitin ligase DCST1 as a novel negative regulator of Type-I interferon signaling. Sci. Rep. 2016, 6, 1-13. [CrossRef]

148. Ismail, I.H.; McDonald, D.; Strickfaden, H.; Xu, Z.; Hendzel, M.J. A small molecule inhibitor of polycomb repressive complex 1 inhibits ubiquitin signaling at DNA double-strand breaks. J. Biol. Chem. 2013, 288, 26944-26954. [CrossRef]

149. Cao, Y.; Wang, C.; Zhang, X.; Xing, G.; Lu, K.; Gu, Y.; He, F.; Zhang, L. Selective small molecule compounds increase BMP-2 responsiveness by inhibiting Smurf1-mediated Smad1/5 degradation. Sci. Rep. 2014, 4, 1-11. [CrossRef]

150. Zheng, H.; Qian, J.; Varghese, B.; Baker, D.P.; Fuchs, S. Ligand-Stimulated Downregulation of the Alpha Interferon Receptor: Role of Protein Kinase D2. Mol. Cell. Biol. 2011, 31, 710-720. [CrossRef]

151. Azoitei, N.; Cobbaut, M.; Becher, A.; Van Lint, J.; Seufferlein, T. Protein kinase D2: A versatile player in cancer biology. Oncogene 2018, 37, 1263-1278. [CrossRef]

152. Wei, N.; Chu, E.; Wipf, P.; Schmitz, J.C. Protein kinase D as a potential chemotherapeutic target for colorectal cancer. Mol. Cancer Ther. 2014, 13, 1130-1141. [CrossRef]

153. Tandon, M.; Salamoun, J.M.; Carder, E.J.; Farber, E.; Xu, S.; Deng, F.; Tang, H.; Wipf, P.; Wang, Q.J. SD-208, a novel protein kinase D inhibitor, blocks prostate cancer cell proliferation and tumor Growth in Vivo by inducing G2/M cell cycle arrest. PLoS ONE 2015, 10, 1-19. [CrossRef] [PubMed] 
154. Meissner, T.B.; Li, A.; Biswas, A.; Lee, K.H.; Liu, Y.J.; Bayir, E.; Iliopoulos, D.; Van Den Elsen, P.J.; Kobayashi, K.S. NLR family member NLRC5 is a transcriptional regulator of MHC class I genes. Proc. Natl. Acad. Sci. USA 2010, 107, 13794-13799. [CrossRef] [PubMed]

155. Staehli, F.; Ludigs, K.; Heinz, L.X.; Seguín-Estévez, Q.; Ferrero, I.; Braun, M.; Schroder, K.; Rebsamen, M.; Tardivel, A.; Mattmann, C.; et al. NLRC5 Deficiency Selectively Impairs MHC Class I- Dependent Lymphocyte Killing by Cytotoxic T Cells. J. Immunol. 2012, 188, 3820-3828. [CrossRef] [PubMed]

156. Kuenzel, S.; Till, A.; Winkler, M.; Häsler, R.; Lipinski, S.; Jung, S.; Grötzinger, J.; Fickenscher, H.; Schreiber, S.; Rosenstiel, P. The Nucleotide-Binding Oligomerization Domain-Like Receptor NLRC5 Is Involved in IFN-Dependent Antiviral Immune Responses. J. Immunol. 2010, 184, 1990-2000. [CrossRef]

157. Kobayashi, K.S.; Van Den Elsen, P.J. NLRC5: A key regulator of MHC class I-dependent immune responses. Nat. Rev. Immunol. 2012, 12, 813-820. [CrossRef]

158. Ozcan, M.; Janikovits, J.; von Knebel Doeberitz, M.; Kloor, M. Complex pattern of immune evasion in MSI colorectal cancer. Oncoimmunology 2018, 7, 1-10. [CrossRef]

159. Yoshihama, S.; Roszik, J.; Downs, I.; Meissner, T.B.; Vijayan, S.; Chapuy, B.; Sidiq, T.; Shipp, M.A.; Lizee, G.A.; Kobayashi, K.S. NLRC5/MHC class I transactivator is a target for immune evasion in cancer. Proc. Natl. Acad. Sci. USA 2016, 113, 5999-6004. [CrossRef]

160. Rodriguez, G.M.; Bobbala, D.; Serrano, D.; Mayhue, M.; Champagne, A.; Saucier, C.; Steimle, V.; Kufer, T.A.; Menendez, A.; Ramanathan, S.; et al. NLRC5 elicits antitumor immunity by enhancing processing and presentation of tumor antigens to CD8+ T lymphocytes. Oncoimmunology 2016, 5, 1-12. [CrossRef]

161. Tang, F.; Xu, Y.; Zhao, B. NLRC5: New cancer buster? Mol. Biol. Rep. 2020, 47, 2265-2277. [CrossRef] [PubMed]

162. Huynh, J.; Chand, A.; Gough, D.; Ernst, M. Therapeutically exploiting STAT3 activity in cancer-using tissue repair as a road map. Nat. Rev. Cancer 2019, 19, 82-96. [CrossRef]

163. Blaskovich, M.A.; Sun, J.; Cantor, A.; Turkson, J.; Jove, R.; Sebti, S.M. Discovery of JSI-124 (cucurbitacin I), a selective Janus kinase/signal transducer and activator of transcription 3 signaling pathway inhibitor with potent antitumor activity against human and murine cancer cells in mice. Cancer Res. 2003, 63, 1270-1279.

164. Nam, S.; Buettner, R.; Turkson, J.; Kim, D.; Cheng, J.Q.; Muehlbeyer, S.; Hippe, F.; Vatter, S.; Merz, K.H.; Eisenbrand, G.; et al. Indirubin derivatives inhibit Stat3 signaling and induce apoptosis in human cancer cells. Proc. Natl. Acad. Sci. USA 2005, 102, 5998-6003. [CrossRef] [PubMed]

165. Kotha, A.; Sekharam, M.; Cilenti, L.; Siddiquee, K.; Khaled, A.; Zervos, A.S.; Carter, B.; Turkson, J.; Jove, R. Resveratrol inhibits Src and Stat 3 signaling and induces the apoptosis of malignant cells containing activated Stat3 protein. Mol. Cancer Ther. 2006, 5, 621-629. [CrossRef] [PubMed]

166. Schust, J.; Sperl, B.; Hollis, A.; Mayer, T.U.; Berg, T. Stattic: A Small-Molecule Inhibitor of STAT3 Activation and Dimerization. Chem. Biol. 2006, 13, 1235-1242. [CrossRef]

167. Yang, F.; Van Meter, T.E.; Buettner, R.; Hedvat, M.; Liang, W.; Kowolik, C.M.; Mepani, N.; Mirosevich, J.; Nam, S.; Chen, M.Y.; et al. Sorafenib inhibits signal transducer and activator of transcription 3 signaling associated with growth arrest and apoptosis of medulloblastomas. Mol. Cancer Ther. 2008, 7, 3519-3526. [CrossRef]

168. Xin, H.; Zhang, C.; Herrmann, A.; Du, Y.; Figlin, R.; Yu, H. Sunitinib inhibition of Stat3 induces renal cell carcinoma tumor cell apoptosis and reduces immunosuppressive cells. Cancer Res. 2009, 69, 2506-2513. [CrossRef]

169. McFarland, B.C.; Gray, G.K.; Nozell, S.E.; Hong, S.W.; Benveniste, E.N. Activation of the NF-kB pathway by the STAT3 inhibitor JSI-124 in human glioblastoma cells. Mol. Cancer Res. 2013, 11, 494-505. [CrossRef]

170. Zhu, Y.; Ye, T.; Yu, X.; Lei, Q.; Yang, F.; Xia, Y.; Song, X.; Liu, L.; Deng, H.; Gao, T.; et al. Nifuroxazide exerts potent anti-tumor and anti-metastasis activity in melanoma. Sci. Rep. 2016, 6, 1-13. [CrossRef]

171. Yang, H.; Yamazaki, T.; Pietrocola, F.; Zhou, H.; Zitvogel, L.; Ma, Y.; Kroemer, G. STAT3 inhibition enhances the therapeutic efficacy of immunogenic chemotherapy by stimulating type 1 interferon production by cancer cells. Cancer Res. 2015, 75, 3812-3822. [CrossRef] [PubMed]

172. Lu, C.; Talukder, A.; Savage, N.M.; Singh, N.; Liu, K. JAK-STAT-mediated chronic inflammation impairs cytotoxic T lymphocyte activation to decrease anti-PD-1 immunotherapy efficacy in pancreatic cancer. Oncoimmunology 2017, 6, 1-15. [CrossRef] 
173. Cohen, E.E.W.; Harrington, K.J.; Hong, D.S.; Mesia, R.; Brana, I.; Perez Segura, P.; Wise-Draper, T.; Scott, M.L.; Mitchell, P.D.; Mugundu, G.M.; et al. A phase Ib/II study (SCORES) of durvalumab (D) plus danvatirsen (DAN.; AZD9150) or AZD5069 (CX2i) in advanced solid malignancies and recurrent/metastatic head and neck squamous cell carcinoma (RM-HNSCC): Updated results. Ann. Oncol. Off. J. Eur. Soc. Med. Oncol. 2018, 29, viii372. [CrossRef]

174. D'amico, S.; Shi, J.; Martin, B.L.; Crawford, H.C.; Petrenko, O.; Reich, N.C. STAT3 is a master regulator of epithelial identity and KRAS-driven tumorigenesis. Genes Dev. 2018, 32, 1175-1187. [CrossRef] [PubMed]

175. Barber, G.N. STING: Infection, inflammation and cancer. Nat. Rev. Immunol. 2015, 15, 760-770. [CrossRef] [PubMed]

176. Abe, T.; Barber, G.N. Cytosolic-DNA-Mediated, STING-Dependent Proinflammatory Gene Induction Necessitates Canonical NF- B Activation through TBK1. J. Virol. 2014, 88, 5328-5341. [CrossRef] [PubMed]

177. Challa, S.V.; Zhou, S.; Sheri, A.; Padmanabhan, S.; Meher, G.; Gimi, R.; Schmidt, D.; Cleary, D.; Afdhal, N.; Iyer, R. Preclinical studies of SB 11285, a novel STING agonist for immuno-oncology. J. Clin. Oncol. 2017, 35, e14616. [CrossRef]

178. Wang-Bishop, L.; Wehbe, M.; Shae, D.; James, J.; Hacker, B.C.; Garland, K.; Chistov, P.P.; Rafat, M.; Balko, J.M.; Wilson, J.T. Potent STING activation stimulates immunogenic cell death to enhance antitumor immunity in neuroblastoma. J. Immunother. Cancer 2020, 8, 1-17. [CrossRef]

179. Ager, C.R.; Reilley, M.J.; Nicholas, C.; Bartkowiak, T.; Jaiswal, A.R.; Curran, M.A. Intratumoral STING activation with T-cell checkpoint modulation generates systemic antitumor immunity. Cancer Immunol. Res. 2017, 5, 676-684. [CrossRef]

180. Ghaffari, A.; Peterson, N.; Khalaj, K.; Vitkin, N.; Robinson, A.; Francis, J.A.; Koti, M. Sting agonist therapy in combination with pd-1 immune checkpoint blockade enhances response to carboplatin chemotherapy in high-grade serous ovarian cancer. Br. J. Cancer 2018, 119, 440-449. [CrossRef]

181. Meric-Bernstam, F.; Sandhu, S.K.; Hamid, O.; Spreafico, A.; Kasper, S.; Dummer, R.; Shimizu, T.; Steeghs, N.; Lewis, N.; Talluto, C.C.; et al. Phase Ib study of MIW815 (ADU-S100) in combination with spartalizumab (PDR001) in patients (pts) with advanced/metastatic solid tumors or lymphomas. J. Clin. Oncol. $2019,37$. [CrossRef]

182. Seliger, B.; Harders, C.; Lohmann, S.; Momburg, F.; Urlinger, S.; Tampé, R.; Huber, C. Down-regulation of the MHC class I antigen-processing machinery after oncogenic transformation of murine fibroblasts. Eur. J. Immunol. 1998, 28, 122-133. [CrossRef]

183. Herrmann, F.; Lehr, H.A.; Drexler, I.; Sutter, G.; Hengstler, J.; Wollscheid, U.; Seliger, B. HER-2/neu-Mediated Regulation of Components of the MHC Class I Antigen-Processing Pathway. Cancer Res. 2004, 64, 215-220. [CrossRef] [PubMed]

184. Bradley, S.D.; Chen, Z.; Melendez, B.; Talukder, A.; Khalili, J.S.; Rodriguez-Cruz, T.; Liu, S.; Whittington, M.; Deng, W.; Li, F.; et al. BRAFV600E co-opts a conserved MHC class I internalization pathway to diminish antigen presentation and CD8+ T-cell recognition of melanoma. Cancer Immunol. Res. 2015, 3, 602-609. [CrossRef] [PubMed]

185. Brea, E.J.; Oh, C.Y.; Manchado, E.; Budhu, S.; Gejman, R.S.; Mo, G.; Mondello, P.; Han, J.E.; Jarvis, C.A.; Ulmert, D.; et al. Kinase regulation of human MHC class i molecule expression on cancer cells. Cancer Immunol. Res. 2016, 4, 936-947. [CrossRef] [PubMed]

186. Versteeg, R.; Noordermeer, I.A.; Krüse-Wolters, M.; Ruiter, D.J.; Schrier, P.I. c-myc down-regulates class I HLA expression in human melanomas. EMBO J. 1988, 7, 1023-1029. [CrossRef]

187. Yang, W.; Li, Y.; Gao, R.; Xiu, Z.; Sun, T. MHC class I dysfunction of glioma stem cells escapes from CTL-mediated immune response via activation of Wnt/ $\beta$-catenin signaling pathway. Oncogene 2020, 39, 1098-1111. [CrossRef]

188. Lulli, D.; Carbone, M.L.; Pastore, S. The MEK inhibitors trametinib and cobimetinib induce a type I interferon response in human keratinocytes. Int. J. Mol. Sci. 2017, 18, 2227. [CrossRef]

189. Watanabe, S.; Hayashi, H.; Haratani, K.; Shimizu, S.; Tanizaki, J.; Sakai, K.; Kawakami, H.; Yonesaka, K.; Tsurutani, J.; Togashi, Y.; et al. Mutational activation of the epidermal growth factor receptor down-regulates major histocompatibility complex class I expression via the extracellular signal-regulated kinase in non-small cell lung cancer. Cancer Sci. 2019, 110, 52-60. [CrossRef]

190. Sapkota, B.; Hill, C.E.; Pollack, B.P. Vemurafenib enhances MHC induction in BRAFV600E homozygous melanoma cells. Oncoimmunology 2013, 2, e22890. [CrossRef] 
191. Mimura, K.; Ando, T.; Poschke, I.; Mougiakakos, D.; Johansson, C.C.; Ichikawa, J.; Okita, R.; Nishimura, M.I.; Handke, D.; Krug, N.; et al. T cell recognition of HLA-A2 restricted tumor antigens is impaired by the oncogene HER2. Int. J. Cancer 2011, 128, 390-401. [CrossRef] [PubMed]

192. Maruyama, T.; Mimura, K.; Sato, E.; Watanabe, M.; Mizukami, Y.; Kawaguchi, Y.; Ando, T.; Kinouchi, H.; Fujii, H.; Kono, K. Inverse correlation of HER2 with MHC class i expression on oesophageal squamous cell carcinoma. Br. J. Cancer 2010, 103, 552-559. [CrossRef]

193. Hastings, K.; Yu, H.A.; Wei, W.; Sanchez-Vega, F.; Deveaux, M.; Choi, J.; Rizvi, H.; Lisberg, A.; Truini, A.; Lydon, C.A.; et al. EGFR mutation subtypes and response to immune checkpoint blockade treatment in non-small-cell lung cancer. Ann. Oncol. 2019, 30, 1311-1320. [CrossRef] [PubMed]

194. Zage, P.E.; Sirisaengtaksin, N.; Liu, Y.; Gireud, M.; Brown, B.S.; Palla, S.; Richards, K.N.; Hughes, D.P.M.; Bean, A.J. UBE4B levels are correlated with clinical outcomes in neuroblastoma patients and with altered neuroblastoma cell proliferation and sensitivity to epidermal growth factor receptor inhibitors. Cancer 2013, 119, 915-923. [CrossRef] [PubMed]

195. Leibowitz, M.S.; Srivastava, R.M.; Filho, P.A.A.; Egloff, A.M.; Wang, L.; Seethala, R.R.; Ferrone, S.; Ferris, R.L. SHP2 is overexpressed and inhibits pSTAT1-mediated APM component expression, $\mathrm{T}$ cell attracting chemokine secretion, and CTL recognition in head and neck cancer cells. Clin. Cancer Res. 2013, 19, 798-808. [CrossRef] [PubMed]

196. Agazie, Y.M.; Hayman, M.J. Molecular Mechanism for a Role of SHP2 in Epidermal Growth Factor Receptor Signaling. Mol. Cell. Biol. 2003, 23, 7875-7886. [CrossRef]

197. Grandis, J.R.; Drenning, S.D.; Zeng, Q.; Watkins, S.C.; Melhem, M.F.; Endo, S.; Johnson, D.E.; Huang, L.; He, Y.; Kim, J.D. Constitutive activation of stat3 signaling abrogates apoptosis in squamous cell carcinogenesis in vivo. Proc. Natl. Acad. Sci. USA 2000, 97, 4227-4232. [CrossRef]

198. Garrido, G.; Rabasa, A.; Garrido, C.; Chao, L.; Garrido, F.; García-Lora, Á.M.; Sánchez-Ramírez, B. Upregulation of HLA Class I Expression on Tumor Cells by the Anti-EGFR Antibody Nimotuzumab. Front. Pharmacol. 2017, 8,1-11. [CrossRef]

199. Srivastava, R.M.; Trivedi, S.; Concha-Benavente, F.; Hyun-Bae, J.; Wang, L.; Seethala, R.R.; Branstetter IV, B.F.; Ferrone, S.; Ferris, R.L. Stat1-induced HLA class i upregulation enhances immunogenicity and clinical response to anti-EGFR mab cetuximab therapy in HNC patients. Cancer Immunol. Res. 2015, 3, 936-945. [CrossRef] [PubMed]

200. Pollack, B.P.; Sapkota, B.; Cartee, T.V. Epidermal growth factor receptor inhibition augments the expression of MHC class I and II genes. Clin. Cancer Res. 2011, 17, 4400-4413. [CrossRef]

201. Freeman, A.J.; Vervoort, S.J.; Ramsbottom, K.M.; Kelly, M.J.; Michie, J.; Pijpers, L.; Johnstone, R.W.; Kearney, C.J.; Oliaro, J. Natural Killer Cells Suppress T Cell-Associated Tumor Immune Evasion. Cell Rep. 2019, 28, 2784-2794.e5. [CrossRef] [PubMed]

202. He, S.; Yin, T.; Li, D.; Gao, X.; Wan, Y.; Ma, X.; Ye, T.; Guo, F.; Sun, J.; Lin, Z.; et al. Enhanced interaction between natural killer cells and lung cancer cells: Involvement in gefitinib-mediated immunoregulation. $J$. Transl. Med. 2013, 11, 1. [CrossRef] [PubMed]

203. Van't Veer, L.J.; Beijersbergen, R.L.; Bernards, R. N-myc suppresses major histocompatibility complex class I gene expression through down-regulation of the p50 subunit of NF-kappa B. EMBO J. 1993, 12, 195-200. [CrossRef]

204. Forloni, M.; Albini, S.; Limongi, M.Z.; Cifaldi, L.; Boldrini, R.; Nicotra, M.R.; Giannini, G.; Natali, P.G.; Giacomini, P.; Fruci, D. NF-kB, and not MYCN, regulates MHC class I and endoplasmic reticulum aminopeptidases in human neuroblastoma cells. Cancer Res. 2010, 70, 916-924. [CrossRef] [PubMed]

205. Hodge, J.W.; Garnett, C.T.; Farsaci, B.; Palena, C.; Tsang, K.Y.; Ferrone, S.; Gameiro, S.R. Chemotherapy-induced immunogenic modulation of tumor cells enhances killing by cytotoxic T lymphocytes and is distinct from immunogenic cell death. Int. J. Cancer 2013, 133, 624-636. [CrossRef] [PubMed]

206. Khallouf, H.; Märten, A.; Serba, S.; Teichgräber, V.; Büchler, M.W.; Jäger, D.; Schmidt, J. 5-fluorouracil and interferon- $\alpha$ immunochemotherapy enhances immunogenicity of murine pancreatic cancer through upregulation of NKG2D ligands and MHC class i. J. Immunother. 2012, 35, 245-253. [CrossRef]

207. Wan, S.; Pestka, S.; Jubin, R.G.; Lyu, Y.L.; Tsai, Y.C.; Liu, L.F. Chemotherapeutics and radiation stimulate MHC class i expression through elevated interferon-beta signaling in breast cancer cells. PLoS ONE 2012, 7, e32542. [CrossRef] 
208. Iwai, T.; Sugimoto, M.; Wakita, D.; Yorozu, K.; Kurasawa, M.; Yamamoto, K. Topoisomerase I inhibitor, irinotecan, depletes regulatory T cells and up-regulates MHC class I and PD-L1 expression, resulting in a supra-additive antitumor effect when combined with anti- PD-L1 antibodies. Oncotarget 2018, 9, 31411-31421. [CrossRef]

209. Alagkiozidis, I.; Facciabene, A.; Tsiatas, M.; Carpenito, C.; Benencia, F.; Adams, S.; Jonak, Z.; June, C.H.; Powell, D.J.; Coukos, G. Time-dependent cytotoxic drugs selectively cooperate with IL-18 for cancer chemo-immunotherapy. J. Transl. Med. 2011, 9, 77. [CrossRef]

210. De Mora-García, M.L.; Duenas-González, A.; Hernández-Montes, J.; De la Cruz-Hernández, E.; Pérez-Cárdenas, E.; Weiss-Steider, B.; Santiago-Osorio, E.; Ortíz-Navarrete, V.F.; Rosales, V.H.; Cantú, D.; et al. Up-regulation of HLA class-I antigen expression and antigen-specific CTL response in cervical cancer cells by the demethylating agent hydralazine and the histone deacetylase inhibitor valproic acid. J. Transl. Med. 2006, 4, 1-14. [CrossRef]

211. Khan, A.N.H.; Gregorie, C.J.; Tomasi, T.B. Histone deacetylase inhibitors induce TAP, LMP, Tapasin genes and MHC class I antigen presentation by melanoma cells. Cancer Immunol. Immunother. 2008, 57, 647-654. [CrossRef] [PubMed]

212. Ritter, C.; Fan, K.; Paschen, A.; Reker Hardrup, S.; Ferrone, S.; Nghiem, P.; Ugurel, S.; Schrama, D.; Becker, J.C. Epigenetic priming restores the HLA class-I antigen processing machinery expression in Merkel cell carcinoma. Sci. Rep. 2017, 7, 1-11. [CrossRef]

213. Setiadi, A.F.; Omilusik, K.; David, M.D.; Seipp, R.P.; Hartikainen, J.; Gopaul, R.; Choi, K.B.; Jefferies, W.A. Epigenetic enhancement of antigen processing and presentation promotes immune recognition of tumors. Cancer Res. 2008, 68, 9601-9607. [CrossRef] [PubMed]

214. Suraweera, A.; O’Byrne, K.J.; Richard, D.J. Combination therapy with histone deacetylase inhibitors (HDACi) for the treatment of cancer: Achieving the full therapeutic potential of HDACi. Front. Oncol. 2018, 8, 1-15. [CrossRef] [PubMed]

215. Serrano, A.; Tanzarella, S.; Lionello, I.; Mendez, R.; Traversari, C.; Ruiz-Cabello, F.; Garrido, F. Expression of HLA class I antigens and restoration of antigen-specific CTL response in melanoma cells following 5-aza-2'-deoxycytidine treatment. Int. J. Cancer 2001, 94, 243-251. [CrossRef]

216. Luo, N.; Nixon, M.J.; Gonzalez-Ericsson, P.I.; Sanchez, V.; Opalenik, S.R.; Li, H.; Zahnow, C.A.; Nickels, M.L.; Liu, F.; Tantawy, M.N.; et al. DNA methyltransferase inhibition upregulates MHC-I to potentiate cytotoxic T lymphocyte responses in breast cancer. Nat. Commun. 2018, 9, 248. [CrossRef]

217. Fonsatti, E.; Nicolay, H.J.M.; Sigalotti, L.; Calabrò, L.; Pezzani, L.; Colizzi, F.; Altomonte, M.; Guidoboni, M.; Marincola, F.M.; Maio, M. Functional up-regulation of human leukocyte antigen class I antigens expression by 5-aza-2'-deoxycytidine in cutaneous melanoma: Immunotherapeutic implications. Clin. Cancer Res. 2007, 13, 3333-3338. [CrossRef]

218. Santin, A.D.; Hermonat, P.L.; Ravaggi, A.; Chiriva-Internati, M.; Pecorelli, S.; Parham, G.P. Retinoic acid up-regulates the expression of major histocompatibility complex molecules and adhesion/costimulation molecules (specifically, intercellular adhesion molecule ICAM-1) in human cervical cancer. In Proceedings of the American Journal of Obstetrics and Gynecology; Mosby Inc.: St. Louis, MO, USA, 1998; Volume 179, pp. 1020-1025.

219. Castriconi, R.; Dondero, A.; Cilli, M.; Ognio, E.; Pezzolo, A.; De Giovanni, B.; Gambini, C.; Pistoia, V.; Moretta, L.; Moretta, A.; et al. Human NK cell infusions prolong survival of metastatic human neuroblastoma-bearing NOD/scid mice. Cancer Immunol. Immunother. 2007, 56, 1733-1742. [CrossRef]

(C) 2020 by the authors. Licensee MDPI, Basel, Switzerland. This article is an open access article distributed under the terms and conditions of the Creative Commons Attribution (CC BY) license (http://creativecommons.org/licenses/by/4.0/). 